九州大学学術情報リポジトリ

Kyushu University Institutional Repository

\title{
The Composition of Decomposition : The Kusōzu Images of Matsui Fuyuko and Itō Seiu, and Buddhism in Erotic Grotesque Modernity
}

Tinsley, Elizabeth

Metropolitan Museum of Art : Andrew W. Mellon Art History Fellow | Department of religion, Columbia University : Doctoral Candidate

https://doi.org/10.5109/1806128

出版情報: Journal of Asian Humanities at Kyushu University. 2, pp.15-45, 2017-03. Kyushu University, School of Letters, Graduate School of Humanities, Faculty of Humanities バージョン:

権利関係 : 


\title{
The Composition of Decomposition: The Kusōzu Images of Matsui Fuyuko and Itō Seiu, and Buddhism in Erotic Grotesque Modernity
}

\author{
ELIZABETH TINSLEY \\ "What looks like meaningful, divine suffering to one person \\ often looks like brutal, preventable violence to another."
}

\section{Introduction}

N Buddhist culture, the young and beautiful female as corpse has often been presented as a sight of soteriological potential, a demonstration of the illusions of beauty, permanence, and identity coherence. A series of paintings ${ }^{2}$ by Matsui Fuyuko 松井冬子 (b. 1974) is only the most recent example of the genre known as “kusōzu” 九相[想]図 (Pictures of the Nine Stages [of a decaying corpse]) (henceforth kusōzu), ${ }^{3}$ which depicts the subject. Some half-century earlier, Itō Seiu 伊藤晴 雨 $(1882-1961)^{4}$ had also produced a substantial corpus of kusozzu. This essay examines the ways in which these artists treat the theme and how the work of Seiu and the visual culture of his time are discernible in the art of Matsui. Matsui distinguishes her series from

Maggie Nelson, The Art of Cruelty: A Reckoning (New York: W. W. Norton \& Company, 2011), 176.

2 At the time of writing, the series is still in progress.

3 The kusōzu is also called a kusō mandara 九相曼茶羅 (nine-stage mandala) and, as a pictorial representation of the human realm in the rokudo-e 六道絵 (picture of the six realms) genre, it is called jindōfujōsōzu 人道不浄相図 (picture of the aspect of the impure human realm).

4 Hereafter referred to as "Seiu," his artist's name. the genre as it is generally understood by presenting the nine states of decomposition as the results of nine motives for suicide. This, in addition to a number of other aspects of her work, makes the series considerably different from its purported model, and links it to an alternative cultural genealogy. To show this, I will summarize the general understanding of $k u s o ̄ z u$ as it has been presented so far in scholarship, and will discuss the erotic and grotesque aspects of $k u s \bar{o} z u$, before introducing the works of Seiu, with a brief explanation of eroguro エログロ (“erotic-grotesque”). I will then consider interpretations of Matsui's series based on a connection with premodern $k u s \bar{z} z u$ and position it within modern Japanese visual culture. The somewhat extensive introduction serves to support my suggestion that Matsui's visual influences, which I locate in the cultural history and images of anatomical dissection, the nude in Japanese art, and of self-mutilation/suicide, are all what we might call, if not Buddhist "corpse contemplations," "dismemberment contemplations" of one kind or another. By reconceiving the genre within this broader category we can release it from a hermeneutics that confines it to a "religious" framework. Other works of her oeuvre support this, and help to shift interpretation of her kusōzu series away from the contention that 
it is a simplistic reworking of Buddhist imagery. The origins of this "contemplation of dismemberment" are to be found not only in Buddhist thought and practice, but in the aesthetic of the grotesque, which was properly developed in Japan, especially as eroguro, during the modern period and which engages all three visual influences - anatomical dissection, the nude in Japanese art, and self-mutilation/suicide-mentioned above. Thus, we find a convergence of Buddhist ideas and visual culture with those of the grotesque, a convergence that helps us to reappraise both. I additionally propose that even though the types of gazes prompted by the subjects of depictions of bodies of the dissected, of the nude, of suicide, and the grotesque (as a general visual aesthetic), and the functions of those gazes appear to be significantly different, they in fact present similarities with those ideally galvanized by the kusōzu. The main similarity is in the treatment of unstable boundaries and [dis]memberment. The types of gazes also present comparable anxieties concerning the act of looking.

Through examining Matsui's paintings in the contexts of the western nude/classical body in Meiji-period Japanese academic art, anatomical dissection, suicide, and the aesthetics of the European grotesque and Japanese eroguro, I show that the strongest influence on her work is late nineteenth-century to mid-twentieth-century Japanese culture, particularly the "interwar period" of the 1920 s and ' 30 , and the immediate post-war period, a period in which Seiu was active. ${ }^{5}$ The reason Matsui's influences can be found here is because the period was one of development of new ways of viewing the body and death, which included interest in, and aestheticized, various types of dismemberment. Moreover, these interests and aesthetics are motifs of modernity in this period rather than those of a backlash against it, which complicates understandings of her art that present it as a harmonious fusion of east and west, tradition and modernity. Matsui's work and its influences also provide an excellent demonstration of Anthony Giddens's suggestion that modernity is not a destruction of tradition but a negotiation between the two. It also coheres to some extent with John D. Szostak's observations on “anti-bijin" “美人 nihonga 日本画 ("Japanese painting") portraiture of the 1910s and '2os in his study that also investigates "modern" versions of "traditional" subject matter and addresses the grotesque aesthetic identified in them. ${ }^{7}$

Appraisal of Matsui's work can be divided into two types. On the one hand, her use of nihonga techniques and materials and of "traditional" Japanese subject matter is lauded by the art establishment and popular critics as a revival of these forms and contents. Her art is similarly celebrated for the way it mixes nihonga and $y \bar{o} g a$ 洋画 (“Western painting") techniques and themes. The ongoing promotion of art that achieves this combination (in specific ways) is evidence of the sustainment of the policy expressed in the compound term wakon $y \bar{o} s a i$ 和魂洋才 (“Japanese spirit, western technology”) employed during the late nineteenth century. Matsui is regularly featured on educational programs made by NHK (Japan Broadcasting Corporation) and her work has been exhibited at the Yokohama Museum of Art and San Francisco's Asian Art Museum. Engaging with "traditional" figures, a collaboration saw motifs from her paintings used as patterns on kimono obi by the celebrated Yamaguchi Genbee 山口原兵衛 (b. 1948). On the other hand, her work is also situated within the modern eroguro and gothic genres, and is often exhibited alongside both Japanese and non-Japanese works that celebrate these aesthetics, for example at Gallery Naruyama, a Tokyo-based gallery that has represented her. Her work also features on websites of often unsettlingly violent materials that appeal to enthusiasts of S\&M and other subcultural fetishes. Matsui's art, then, appeals on two levels simultaneously since it is implicated both in a high culture that promotes officially sanctioned national identity and in subversive subcultures. Two additional levels her work occupies are the
5 This is not to disregard the connections to late twentieth-century art both Japanese and non-Japanese, such as works by Aida Makoto, Hans Bellmer, and Joel-Peter Witkin, that Matsui cites in her own doctoral dissertation and in interviews, but rather to draw to the surface a collection of submerged and largely overlooked influences. See Matsui Fuyuko, "Chikaku shinkei to shite no shikaku ni yotte kakusei sareru tsūkaku no fukahi" (PhD diss., Tokyo University of the Arts, 2007). There are also some significant links with postwar sado-masochistic images, but these will, for the most part, be put aside in this paper.
6 Bijin literally means "beautiful women" and pictures of them (bijinga 美人画) were portrayals of their appearances and customs. 7 Szostak mentions Giddens in his introduction. My definition of "grotesque," however, completely differs from Szostak's. He employs the word as an adjective meaning "repulsive" in terms of marked divergence from beauty norms; mine is both broade and more specific, as explained below. John D. Szostak, "Fair is Foul, and Foul is Fair: Kyoto Nihonga, Anti-Bijin Portraiture and the Psychology of the Grotesque," in Rethinking Japanese Modernism, ed. Roy Starrs (Leiden: Koninklijke Brill NV, 2012), 362. 
(ostensibly) religious and secular, which may be correlated to the high/low-culture dualism mentioned, a point to which I will return. Art historian Yamamoto Satomi's somewhat defensive insistence that "because of her command of the delicate sensitivity enabled by Nihonga techniques and materials, Matsui Fuyuko's works never strike the viewer as merely bizarre or in bad taste, regardless of what their motifs may be," ${ }^{\text {hints }}$ by its apparent necessity at the potential for charges that might be brought against the odd co-existence of the elements we find in her works. Furthermore, it upholds the divide between "high" and "low" cultures. ' The assumption underlying this paper is that the distinctions between religious and secular and between high and low culture are neither simply drawn nor self-evident, and that the grotesque, the essence of which is "the sense that things that should be kept apart are fused together," ${ }^{\prime 10}$ can be a reminder of this.

\section{Scriptural origins of the kusōzu genre and Japanese kusōzu}

The liberating power of the female body viewed as a grotesque corpse may be traced to an episode in the biography of the Buddha. Upon renunciation of palace life, he views the sleeping women of his harem, and by perceiving them as bereft of beauty "unconscious, with their garments spread out unfastened .... a if they were dead," appearances. In canonical Buddhist texts the contemplation of the sight of real cadavers in the process of decomposition is prescribed by the Satipatthāna Sutta (The Foundations of Mindfulness Sutra) where "The Nine Charnel Ground Contemplations" are found. ${ }^{12}$

8 Satomi Yamamoto, "Beyond," in Becoming Friends with All the Children in the World, ed. Fuyuko Matsui (Tokyo: Éditions Treville, 2013), 169 .

9 Interestingly, here it is form, rather than content, that determines the affiliation of a work to one or other culture level. Here, as long as certain materials are used and certain techniques are executed well, the work cannot as a whole be in "bad taste"

10 Geoffrey Harpham, On the Grotesque: Strategies of Contradiction in Art and Literature (Princeton: Princeton University Press, 1982), 11.

11 Aśvaghosa, ed. and trans. Edward B. Cowell, The Buddha-Karita, or, Life of the Buddha (New Delhi: Cosmo Publications, 1977), Book 5, 58,60.

12 Bikkhu Bodhi and Bikkhu Nanamoli, Teachings of the Buddha: The Middle Length Discourses of the Buddha: A Translation of the Majjhima Nikaya (Somerville: Wisdom Publications, 2005), 148-49.
It is also presented in the Anguttara Nikāya (The Numerical Discourses) ${ }^{13}$ and in the Mahāprajña $\bar{a}$ Pāramitā Sastra (Discourses on the Greater Wisdom Sutra) ${ }^{14}$ by Nāgārjuna (ca. 150-250) as a means to attain insight into the truth of impermanence. It is Tendai founder Zhiyi’s 智顗 (538-97) Mohe zhiguan (Jp. Maka shikan 摩訶止観, Discourse on Mahayana Meditation and Contemplation) of 594 that formulates the contemplation as a practice. ${ }^{15}$

No gender is specified for these morbid objects of meditation, ${ }^{16}$ but the explanation that a "pan-Indian tendency to hold women responsible for the arousal of desire," as given by Elizabeth Wilson, is persuasive enough. ${ }^{17}$ She holds that both Buddhist and non-Bud-

13 Bikkhu Bodhi, The Numerical Discourses of the Buddha: A Translation of the Ariguttara Nikāya (Boston: Wisdom Publications, 2012), 891-92.

14 Jp. Daichi doron 大智度論. T.25, 1509 .

15 T.1911, 46.121 12a-16a and 122 10a-13a. Xuanzang's 玄牀 (6O2-64) translation of Abidatsuma Daibibasharon 阿毘達磨大毘婆沙論 (The Great Abhidharma Discourse, 100-150 CE) also outlined the practice, and the Tendai monk Genshin's 源信 (942-1017) influential Ōjō yōshū 往生要集 (Essentials of Salvation, 985) drew upon this.

16 In the Mahadukkhandha Sutta (The Greater Discourse on the Mass of Suffering), however, a decomposing female corpse in a charnel ground is used as a method of demonstrating the removal of attachment to material form. Bikkhu Bodhi and Bikkhu Nanamoli, Teachings of the Buddha, 183-84.

17 Elizabeth Wilson, "The Female Body as a Source of Horror and In sight in Post-Ashokan Indian Buddhism," in Religious Reflections on the Human Body, ed. Jane Marie Law (Bloomington: Indiana University Press, 1995), 83. See also Elizabeth Wilson, Charming Cadavers: Horrific Figurations of the Feminine in Indian Buddhist Hagiographical Literature (Chicago and London: University of Chicago Press, 1996). For discussions in English of the doctrine and the literary and graphic portrayals of fujōkan 不浄観, meditation on transience (mujō 無常) through contemplation of the impurity of the body, in Japan, see Rajyashree Pandey, "Desire and Disgust: Meditations on the Impure Body in Medieval Japanese Narratives," Monumenta Nipponica 60, no. 2 (2005): 195-234; Fusae Kanda, "Behind the Sensationalism: Images of a Decaying Corpse in Japanese Buddhist Art," The Art Bulletin 87 no. 1 (2005): 24-49; Gail Chin, "The Gender of Buddhist Truth: The Female Corpse in a Group of Japanese Paintings," Japanese Journal of Religious Studies 25, no. 3-4 (1998): 277-317; Ikumi Kaminishi, "Dead Beautiful: Visualizing the Decaying Corpse in Nine Stages as Skillful Means of Buddhism," A Companion to Asian Art and Architecture: Blackwell Companions to Art History, eds. Rebecca Brown and Deborah Hutton (Chichester, West Sussex UK; Malden, MA: Wiley-Blackwell, 2011), 514-36; and Yamamoto Satomi, Kusōzu o yomu: Kuchite yuku shitai no bijutsushi (Tokyo: Kadokawa, 2015). A collection of images with accompanying essays in Japanese is available in Yamamoto Satomi and Nishiyama Mika, Kusōzu shiryō shūsei: Shitai no bijutsu to bungaku (Tokyo: Iwata Shoin, 2009). Keisei's 慶政 (1189-1268) Kankyo no tomo 閑居 友 (A Companion in Solitude, ca. 1222), discussed below, gives an account of a monk undertaking the practice. 
dhist texts that describe women as corpse-like beings painted up to tempt and to deceive led to the female gendering and sexualizing of the corpse in many postAshokan narratives and images. As such, the service performed by the image of the female in these tales is ostensibly twofold. It functioned to evoke disgust and horror and thereby to nullify (hetero)sexual desire, reinforcing vows of celibacy. At the same time, it worked to wrest practitioners free of delusional attachments to the physical body that, according to Buddhist doctrine, is but a composition of aggregates, and can be seen more widely as a depiction of "the structures of the [Buddhist] renouncer's moral world, especially its ephemeral and intrinsically dissatisfying nature." ${ }^{\prime 18}$ In Matsui's paintings of the disaggregated female corpse created in the early twenty-first century and modeled on earlier "Buddhist" presentations of the image, the second basic function remains operative, which accords with the artist's intention. The former, probably just as prescriptive as the latter, is subverted by Matsui: that there is a gendered, eroticized, and titillating element to kusozzu, even or rather central to the images of the stages of decomposition and desecration, is fully acknowledged. Matsui's renditions of kusōzu exploit the pornographic mechanism they share that turns on the exhibited process of beauty, exposure, degradation and ruin within a gendered hierarchy. It is my contention, however, that these functions, and many other key aesthetic and conceptual aspects of her images, emerge, as mentioned, within a surprising network of recent practices, artistic influences, and symbols. Before addressing these, I will discuss her initially more immediate inspiration and model, kusōzu in Japan. This description and discussion will help to show how she draws upon the model, and also how the model itself is already a fertile site for the grotesque and eroguro to evolve in part because it is already open to viewing and interpretation beyond what is prescribed.

Mentions of fujōkan 不浄観, meditation on transience (mujo 無常) through contemplation of the impurity of the body, appear in Buddhist sutras that had been imported from China to Japan, and in Japanese literature from around the ninth century. There is no direct evidence that fujōkan was practiced in Japan with real corpses, but textual descriptions and visual aids

18 Wilson, "The Female Body as a Source of Horror and Insight in Post-Ashokan Indian Buddhism," 93. survive as evidence of surrogate meditation tools. ${ }^{19}$ For example, the Hokke gengi 法華玄義 (Profound Meaning of the Lotus Sutra, a sixth-century Tendai treatise by Zhiyi who taught the previously mentioned Maka shikan) categorizes meditation on a corpse as a beneficial practice and prescribes "making a space [bōsha 房舍] or a painting zuga [図画]" for the purpose. ${ }^{20}$ Zen monk Musō Soseki 無双漱石 (1275-1351) is reported to have made and meditated on a portrayal of the nine stages of corpse decomposition at the age of thirteen. ${ }^{21}$ In medieval Japanese Buddhist narratives, fujōkan was a potent literary theme as well, coming to denote the impermanence of romantic attachment; ${ }^{22}$ but in the extant visual representations (which far exceed the literary ones) ${ }^{23}$ the corpse is almost always female, and the portrayal far from romantic. The following discussion is intended to foreground the key characteristics of kusōzu in Japan, including the gendered body in it, and to indicate the related instability of the divide between sacred and secular concerning the function of the image and the type of viewing it invites. This will lead us into the modes of viewing that become more prominent in certain areas of early twentieth-century culture, with which Matsui plays in her own versions.

\section{Gender, Image Function, and Ways of Seeing}

Kusōzu have maintained a grip on spectators for many centuries and exercise a persistent allure for recent scholars of art history and Buddhist culture. In Japan, the paintings appeared from the early thirteenth century onward in the form of hanging scrolls and handscrolls. Their subject spread widely in the form of woodblock printed books from around the seventeenth century, signifying a shift to a lay and popular audience. For images of transience, the marked longevity and, in printed form, relatively wide circulation they enjoyed is ironic. Like the practice of meditation on a corpse, they were ostensibly intended as meditation aids. However,

\footnotetext{
19 Such surrogate pictures are found elsewhere, such as in the Central Asian Toyuk grottoes.

20 T.1716, 33.727 26a-28a.

21 Kaminishi, "Dead Beautiful," 521

22 Pandey, "Desire and Disgust," 197.

23 Its appearance as a literary trope in Japan is rare; in India it was
} employed far more often. Pandey, "Desire and Disgust," 196. 
Yamamoto notes that, at least during the Muromachi period (1392-1573), handscrolls of the theme seem to have been popular among the upper classes and that, while the careful record of their production dates indicates they were used for specific Buddhist rites, the combination of Chinese arts and Japanese poetry they showcase indicates that they may have been used on a "semi-secular, semi-religious occasion" like a Buddhist-related linked-verse meeting. ${ }^{24} \mathrm{~A}$ citation in a seventeenth-century fan design by Tawaraya Sōtatsu 俵屋宗達 ( $f$ l. early seventeenth century) of one stage of corpse disintegration from a Kamakura-period (1185-1333) rendition also suggests that the content was not strictly confined to a monastic meditation context and that it may have been well known. Two dogs were copied from the kusōzu, likely for their lively poses. ${ }^{25}$ The slide (or, rather, the false distinction) between religious and secular is already evident; we will find it again in the twentieth-century kusōzu renditions and their receptions. Kaminishi Ikumi also takes pains to avoid positing a stable function for the images and distinguishes between the ways in which Tendai, Zen, and Pure Land monks, as well as laypeople, all used the images. A multiplicity of functions emerge, including solitary meditation, group sermons focusing on impermanence and/or female impurity for the purpose of conversion, and broadly, as representations of the human realm. Kaminishi likens the process in which social and cultural factors produce interpretations of the nine-stage decomposition to a "whisper down the lane" game whereby the "original meaning" is replaced "with issues and problems concerning the female gender." 26

Contemplation of the nine aspects of either a real or depicted corpse was called kusōkan 九相観 or $f u$ jōkan (the broader category of the contemplation of impurity). The images displayed a single cadaveralmost always female-decomposing in nine stages (with occasionally a preceding, living state shown), gorged on by wild dogs and crows, and finally reduced in the ninth stage, called "disjointing," to skeletal dismemberment. The bodies are sexualized: aside from the gendering and exposure of the body, the parts revealed and consumed by the scavengers are the genitals, often the breasts, and sometimes the (exposed and culturally eroticized) neck. The Shōjūraigōji 聖衆来 迎寺 painting, Jindōfujōsōzu 人道不浄相図 (Painting of the Impure Aspect of the Human Realm $)^{27}$ from the late thirteenth century (figure 1), is the earliest example of a painted kusōzu and shows the decay of the gradually exposed body depicted in stages from distension to disintegration into dust, and surrounded by canine and avian predators. ${ }^{28}$ The paintings do not necessarily accord precisely with textual precedents either in terms of imagery or the order in which the disintegration is shown, but the Kyushu National Museum's Kusōzukan 九相図巻 (Picture Scroll of the Nine Stages) from the early fourteenth century (the earliest extant standalone kusōzu) largely conforms to the description by Zhiyi in the Maka shikan. ${ }^{29}$ Zhiyi's stages are as follows: chōsō 腸相 (distention), esō 壊相 (tearing), kechizusō 血塗 相 (bleeding), nōransō膿欄相 (rotting), shōosō 青瘀相 (discoloration), tansō 噉相 (being scavenged and consumed), sansō 散相 (scattering), kotsusō 骨相 (white bones), and shōsō 焼相 (bones burnt to ash). An extra stage of newly dead is often added in the paintings.

Let us consider the issue of gender in these images since it is significant in understanding kusōzu as expressive of a grotesque aesthetic. As mentioned, post-Ashokan Indian Buddhist narratives gendered the corpse female, and a woman is depicted here even though the Maka shikan does not specify a female corpse. In Japan, the setsuwa 説話 tale genre too presented it unequivocally as female. ${ }^{30}$ Even in Six Realms mandala paintings the human figure, switching sex as it passes over the "bridge through life," is transformed into a woman in the depiction of the death stage, where

\footnotetext{
24 Satomi Yamamoto, "Death and Disease in Medieval Japanese Painting," Kinjō Gakuin Daigaku ronshū, jinbun kagaku hen 6, no. 2 (2010): 94-5.

25 Sōtatsu's motifs are drawn from the Kyushu National Museum kuzōshi emaki 九相詩絵巻 (Picture Scroll of Poems on the Nine Stages). The fan is part of a fan-decorated folding screen (senmen haritsuke byōbu 扇面貼付屏風) at Daigoji, Kyoto. See Yasumura Toshinobu, "Motīfu: Katachi yokereba subete yoshi," Geijutsu shinchō, April 2014, 31, 33.

26 Kaminishi, "Dead Beautiful," 514, 521.
}

27 Hereafter referred to as "the Shōjūraigōji kusōzu."

28 This is one of a set of paintings that depict the "rokudō" (six paths [of transmigration]) described in Genshin's Ōjō yōshū where Zhiyi's Maka shikan is mentioned. The set is said to have originally belonged to the imperial palace. See Nakano Genzō, Rokudōe no kenkyū (Kyoto: Tankōsha, 1989), 295-8.

29 See Yamamoto, Kusōzu shiryō shūsei, 15-20.

30 See, for example, the thirteenth-century collections Hosshinsh by Kamo no Chōmei 鴨長明 (1155-1216) and the Kankyo no tomo, mentioned above. 


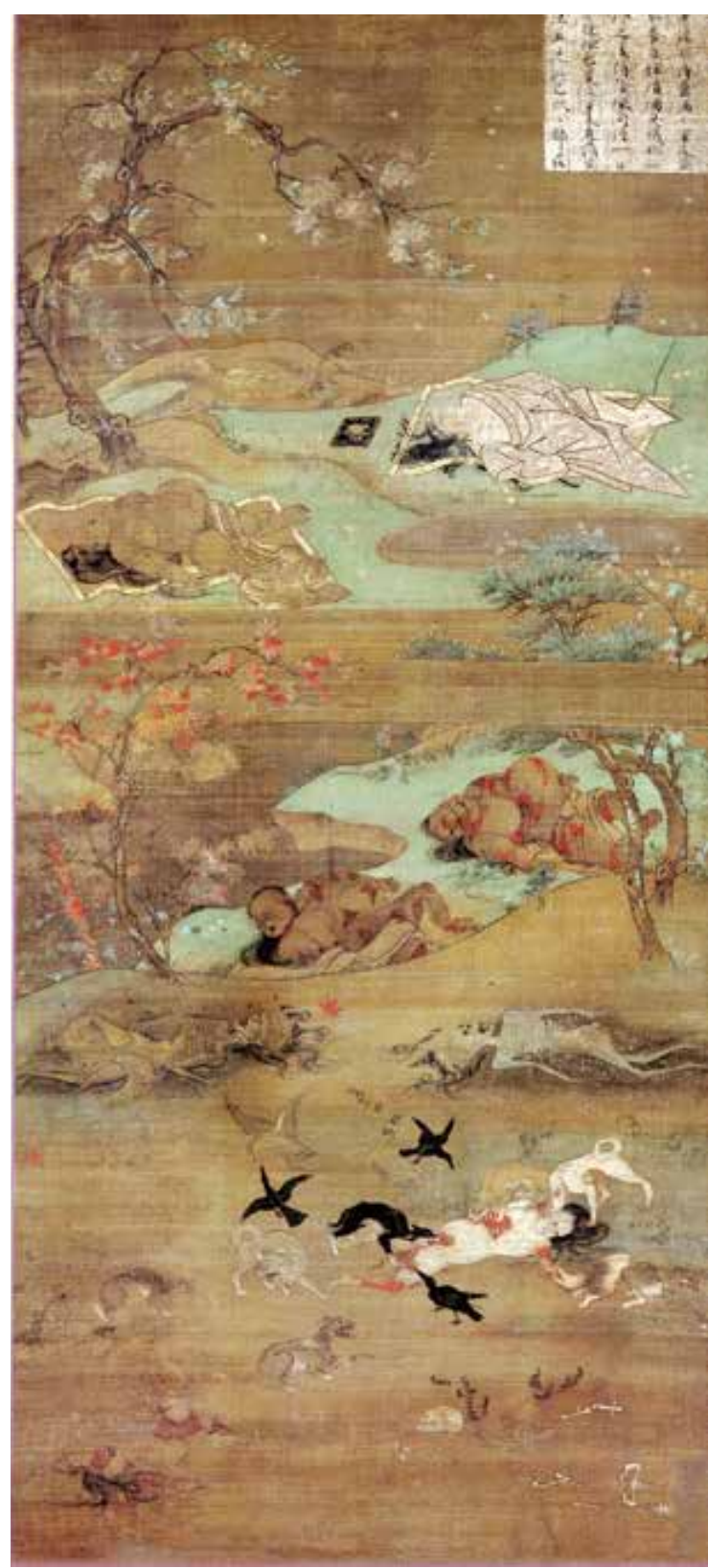

Figure 1. Jindōfujōsōzu 人道不浄相図 (Painting of the Impure Aspect of the Human Realm), late 13th century. H. $155.5 \mathrm{~cm}$, w. $154.5 \mathrm{~cm}$. Hanging scroll. Color on silk. Shōjūraigōji, Shiga. Source: Izumi Takeo, Kasuya Makoto, and Yamamoto Satomi, eds., Kokuhō: Rokudōe (Tokyo: Chūō Kōron Bijutsu Shuppan, 2007), 73, fig. 8. With permission of Shōjūraigoji, Shiga. she appears in a wasteland as food for dogs and crows. ${ }^{31}$ This scene is the most affective of the kusōzu stages. I propose that this scene cannot ideologically accommodate a male body because the gendering and eroticization of the tool of enlightenment is aimed at a spectator seeking to experience the very opposite-closed and contained life - in their own body. If this were not so, a male body would be just as apt a subject in these images as a female one. Still, there are exceptions. A late-Edoperiod series in five hanging scrolls kept at Saiganji 西 岸寺 in Kyoto shows a male corpse. ${ }^{32}$ Nonetheless, the male corpse is presented together with a female one, and while the presence of the male is unusual, and therefore of interest, the immediate impression is that these are a couple. Since the image indicates a heterosexual connection it does not ultimately subvert the significance of gender in kusōzu as it has so far been discussed. This is not to say that the viewer was always a heterosexual male. Viewers of etoki 絵解 (“picture explanation" for the purposes of religious instruction) at temples during the Obon 5 盆 period were of both sexes, and an Edo-period printed picture book, Ninin bikuni 二人比丘尼 (Two Nuns), by Suzuki Shōzan 鈴 木正三 (1579-1655) shows two nuns observing a corpse that is presented in decomposition stages in the style of kusozzu. ${ }^{33}$ Yet they are mourning, in contrast to the non-monastic male figures in the tale, who also view a corpse. But these are exceptions to the rule.

In the 1651 Butsudōji 仏道寺 picture scroll, a male spectator appears - notably, an aristocrat rather than a monk. The “kaimami 垣間見” of this male figure is indicative of the slippage, which Yamamoto has noted, ${ }^{34}$ between sacred and secular in kusōzu. Kaimami is a particular type of viewing-literally "through the fence peeping" - and it is a signature of the aristocratic, ro-

31 Examples can be seen in the many Kumano kanjin jikkai mandara 熊野観心十界曼荼羅 (Visualization of the Heart and Ten Worlds of Kumano) paintings. These were paintings related to pilgrimage at the sacred site of Kumano. They depicted the ten realms of rebirth as well as a bridge-like path along which a human figure progresses in age toward death.

32 These paintings have not yet been published. See Tanaka Takako, "Saiganji shozō 'kusōzu' etoki 'saisei' no kokoromi," Kasamashoin online. http://kasamashoin.jp/2014/12/57_16.html accessed January 4, 2017)

33 Suzuki Shōsan, Shichinin bikuni. Ogura monogatari. Ninin bikuni. Ikkyū mizukagami. Ikkyū gaikotsu. Kusōshi (Tokyo: Benseisha, 1973).

34 Yamamoto, "Death and Disease in Medieval Japanese Painting," 95. 
mantic exploits of well-known literary lovers like Genji and Fujiwara no Ariwara. ${ }^{35}$ Here it functions to twice remove the kusōzu viewer from the corpse subject, but confirms the erotic nature of the gaze. The male spectator within the kusōzu seems to appear in paintings and prints of the Edo period but no earlier. Even if they have always been gendered in Japanese culture, it seems these works became more obviously eroticized as they proliferated into the less monastic spheres of reception. The Saiganji temple kusōzu is peopled with observing figures of all sexes, classes, and types: several meditating men in Chinese-style garments, a pair of welldressed women, two male passers-by, a female deity, and a couple of monks observing the state of complete disintegration but (notably) not meditating. Subjects other than corpses that might include a curious spectator, in addition to the kaimami found in Genji-related paintings, are sideshows, kabuki and bunraku theatre, and erotica. The kusōzu, then, has become a kind of spectacle and, as such, implicit to it is a certain kind of viewing.

The posited function of kusōzu was to recognize oneself in the disintegrating body. But since the body is gendered, arguably the opposite may occur. That is, because the body is female-gendered, and the female is associated with death and permeability (a penetrable body), the observer or meditator becomes male-gendered (even if not male-sexed). This suggestion is further supported by the presence of the often non-monastic male observer who may also evoke tropes of the erotic gaze. To put it differently, it would be necessary for the body to be lacking gender (or for it to be viewed in an alternatively gendered society) in order for the viewer to identify her- or himself with it and realize their "true nature." Let us look at how this is operating in another way: through the use of landscape in visual and literary iterations of the theme. The addition of a landscape, plants, and trees to the images of corpses, another Japanese development, ${ }^{36}$ helps in the gendering and eroticization of the corpse. It also, as we will see,

\footnotetext{
35 Charlotte Eubanks notes this in her analysis of a tale about the contemplation of impurity in Kankyo no tomo and remarks on the presentation of the disintegrating female body as a spectacle. Charlotte Eubanks, Miracles of the Book and Body: Buddhist Textual Culture and Medieval Japan (Berkeley, Los Angeles, London: University of California Press, 2011), 107-8.

36 Kanda, "Behind the Sensationalism," 34-5. The setsuwa tales may be supposed to have provided the landscape images as well, though these landscape elements also drew heavily on Chinese
}

makes it pointedly amenable to interpretation as a "grotesque" body. Kanda and others note that such landscape elements cannot be located in scriptural sources but rather draw on the eleventh-century kusōshi 九相 詩 poem (mis)attributed to Kūkai. ${ }^{37}$ This is relevant to the discussion since the nature of the landscape as well as its position in a territorial configuration of urban, wasteland, and mountainous elements are aspects that produce meaning for the kusōzu female body.

The type of landscape depicted in the paintings suggests the links between fujökan, the femaleness of the corpse, and sexual desire. The arboreal landscape of all seasons in the late-thirteenth-century Shōju Raigōji $k u s \bar{z} z u$ is, as Kanda describes, a metaphor for transience and attention to the mutability of the seasons, and their distinguishing characteristics are hardly unusual in Japanese art as a whole. Yet with its pervasively dark, dull coloring it serves also, she evocatively states, "to convey the gloomy atmosphere of these defiled domains tainted by violence, illness, torture, misery, and a zoo of evils." ${ }^{38}$ However, the addition of landscape should be noted not only in terms of content (the symbolism of trees, plants, and flowers) but also in terms of position. Both aspects are a means of signifying boundaries (or lack thereof): between unbounded nature (female, animal, flora, the viewed, the territorially peripheral/ marginal) and bounded human (male, the viewer, territorially central). The previously mentioned Kankyo no tomo, a story of a monk who practices fujōkan on a corpse, relies for its narrative power on the description of places and their relative positions. ${ }^{39}$ The monk vanishes from his mountain temple each night, returning dispiritedly in the mornings. Both his absence during the night and his forlorn expression are read by other monks as evidence that he is visiting, in the foothills, a woman from whom he is unhappy to be separated. However, upon being followed, it transpires that he is visiting the Rendaino 蓮台野 region (present-day Kita Ward, Kyoto), where many cemeteries were located, to contemplate an exposed corpse. In the assumptions of the monastic community, the locations of the moun-

\footnotetext{
and Japanese poems that described the nine stages with correlating landscape, plant, and animal images. 37 lbid., 31

38 lbid.

39 Koizumi Hiroshi et al., eds., Hōbutsushū. Kankyo no tomo. Hirasan kojin reitaku, vol. 40 of Shin Nihon koten bungaku taikei (Tokyo:
} Iwanami Shoten, 1993), 403-7. 
taintop and its foot, day and night, life and death, are gendered sacred/male and profane/female. ${ }^{40}$ Through this series of oppositions, sex with a woman is tied for the male to the trope of "visiting" a corpse. Although no landscape is described pictorially, designated sites and the distance between them are an effective means of transmitting meaning. There is an emphasis on a pure center and the distance from it. Likewise in the paintings and prints, the female corpse, rendered as increasingly and ultimately boundary-less (decomposing) and as merging with its marginal environment, contrasts with an outer (often implied) territory that is delineated by imposed and artificial borders: the territory of life, centrality, and health from which it has been cast. In threatening to join with it through physical transformation (disintegration), the female image also hints at the troubling potential unity of divisions, a threat to keep in mind as we work through the applicability of the notion of the grotesque to the fujōkan trope.

The aesthetic trope of "the unbounded" is of central importance to the Japanese literary and visual iterations of fujōkan and kusōzu, and later, as I show, to the "grotesque" in modernity. This is why kusōzu resonates with eroguro. As I have suggested above, "the unbounded" is expressed through the female, the landscape, and their iconography and positions. Identifying the trope of the unbounded helps to explain why these images have remained powerful: they are carriers of the grotesquethe conceptual and artistic aesthetic of the threat to boundaries. In the post-Ashokan literary narratives of female corpses as meditation objects as explored by Wilson, "grotesque figurations of the female body are instrumental to men who seek total closure [as a physical and mental ideal promoted by monastic training]. Such closure is out of the question for the body that serves as a liberating spectacle. It is, by nature, an elevated mass of wounds, an array of openings that will not close."41 In this sense, again, apprehension of the disintegrating body is clearly not a lesson in the body as composition of aggregates lacking a locus of essential existence; it

40 At this time, women were excluded from mountains, which had been made the sacred sites of Buddhist temple complexes and were homes of mountain gods. For a recent treatment of this and the scholarship that focuses on it, see Lindsey E. DeWitt, "A Mountain Set Apart: Female Exclusion, Buddhism, and Tradition at Modern Ōminesan, Japan" (PhD diss., University of California, Los Angeles, 2015). At some sites the ban remains today.

41 Wilson, "The Female Body as a Source of Horror and Insight in Post-Ashokan Indian Buddhism," 92; my italics. is, on the contrary, and largely as a result of its sexed and gendered nature, an affirmation of one's own "total closure." Bernard Faure has noted that in some conceptions "the ideal body of the Buddhist practitioner was a closed body, without 'outflows' (a metaphorical designation for defilements)," ${ }^{2}$ and that the physicality of this sealed state was/is difficult or impossible for women. ${ }^{43}$ The unclosed body in the Buddhist tradition is presented as both soteriological/enlightening, and as a "spectacle." Indeed, by being exposed and viewed it is ipso facto a spectacle. We have already observed that the depiction of non-monastic viewers makes the image a spectacle. Connotations of titillation and low culture in the term "spectacle" are, as we will see, apposite too in $k u s \bar{z} z u$ and in literary descriptions of fujōkan from the beginning of the twentieth century onward.

\section{Kusōzu in Twentieth-Century Japanese Visual Culture, and in Itō Seiu's Work}

Given the persistence of the genre, the apparent absence of kusōzu from the Meiji period (1868-1912) onward seems anomalous, as Yamamoto has pointed out. It had enjoyed relatively consistent production from around the thirteenth century onward. Painters of the Kamakura period produced the works already mentioned, and the subject matter was taken up by the Edo-period lineage of Kanō painters, specifically, Kanō Einō 狩野永納 (1631-97), as well as by Kikuchi Yōsai 菊池容斎 (1788-1878) and Kawanabe Kyōsai 河鍋暁 斎 $(1831-89) .{ }^{44}$ Yamamoto offers as possible reasons for the Meiji-period neglect of the subject the rapid modernization of Japan, which necessitated discarding as artistic subject matter certain subjects deemed inappropriate, and the increased quarantining of death itself from post-Meiji everyday life. Additionally, we can assume that, although Buddhism itself came under attack, the de-emphasis on kusōzu was a result of an alignment of Buddhist art with Greek and Roman art in the attempt to put Japanese art on a footing with Western art, as appropriate to a modern power (indeed, to push it into that new category). But clearly, only a

\footnotetext{
42 Bernard Faure, The Red Thread: Buddhist Approaches to Sexuality (Princeton: Princeton University Press, 1998), 61.

43 lbid., 58-62.

44 Yamamoto, "Matsui Fuyuko, Kyūshū de kusōzu o miru," Geijutsu
} shinchō, October 2012, 115 
certain kind of Buddhist art became Japan's "classical."

The apparent disappearance of kusōzu then, appears to mark a sudden break between the premodern and modern - and this contributes, no doubt, to the common linkage of Matsui's work with the earliest premodern examples of the genre. On the other hand, however, Yamamoto does identify aspects of the works of novelists such as eroguro writer Yumeno Kyūsaku 夢野久作 (1889-1936) and Mishima Yukio 三島由紀夫 (1925-70) as kusōzu-inspired. She also introduces nihonga painter Nakamura Gakuryō 中村岳陵 (1890-1969) as proprietor of a fourteenth-century kusōzu painting. Upon his son's departure for the battlefield during the Pacific War he displayed it, informing the young Tanio that he would likely end up "like this" (but that this potential fate was nonetheless a thing of noble beauty). ${ }^{45}$ This is the painted hand-scroll, mentioned above, that is kept at the Kyushu National Museum today, and the work upon which Matsui most closely bases her series. Yamamoto presents these instances of kusōzu "inspiration" as anomalies in a period from which the genre had largely disappeared. To the list may be added the work of Tanizaki Jun'ichirō 谷崎潤一郎 (1886-1965), who details a fujōkan practice of corpse contemplation in his 1949 novella Shōsho Shigemoto no haha 少将滋 幹の母 (Captain Shigemoto's Mother), and, more generally, the writings of Edogawa Rampo 江戸川乱歩 (1894-1965), both discussed below.

Yet there are also notable and unexamined variations of the kusōzu found in the art of Seiu which I present here as an essential aspect of the development of this genre. An illustrator, painter, theatre reviewer, and historian, Seiu was a significant figure in popular Tokyo culture of the early to mid-twentieth century. In many ways he represents a development of the shunga 春画 ("spring [erotic] pictures") and yūreiga 幽霊画 ("ghost pictures”) genres after Tsukioka Yoshitoshi 月岡芳年 (1839-92), and produced work that represents a stage of the flow and development of these two genres into pictorial and photographic pornography in Japan. The work of those who took up these genres was a product of negotiation between the suppression of sexual material and changes in society, technology, and media (such as the growth of visual journalism). One among them, Seiu occupied a prominent position in the early stages of eroguro, and he remains popular today among

45 Yamamoto, “Matsui Fuyuko, Kyūshū de kusōzu o miru," 115.
S\&M enthusiasts with the dubious title of "father" of Japanese rope bondage (縛り/緊縛 shibari/kinbaku). $\mathrm{He}$ is known best as a seme-eshi 責女絵師 (“artist of [scenes of] torture"). The content of his work appealed to the earliest eroguro and pornographic magazines and he was employed as an illustrator by, among others, Kitan Kurabu 奇譚クラブ (Bizarre Stories Club), a post-war magazine publication that specialized in S\&M. His output was vast and, along with newspaper illustrations, paintings, ink works, and theatrical stage props for entertainments in Asakusa (where he was born and lived), he produced illustrated books on Edo and Tokyo customs. He was a compulsive compiler of images and information about all kinds of objects from lampstands, kites, and tea-trays to street signs and children's games, and an enthusiastic recorder of the spectacles and sideshows (misemono 見世物) of the city. Visual technologies such as kaleidoscopes, zoetropes, shadow puppets, and cinema fascinated him. The larger and better-known part of his work, however, was his portrayal of women being tortured, usually ropebound-for him a seemingly inexhaustible subject that he presented in mitate-e 見立て絵 or “intervisual” portrayals ${ }^{46}$ of seasonal customs, scenes from popular theatre, and episodes from "history" and literature. The tortured women in his works were almost always presented as spectacles, with an audience depicted for the publically displayed bodies. When an audience is not provided by direct depiction, montage-like composition guides the viewer. Two pictures in his book Rongo tsūkai 論語通解 (Explanation of Text, 1930), for example, present the violation and consumption by dogs of women hauled from their graves juxtaposed with a parodic spectacle: a Buddhist priest conducts an etoki of a huge painting of a vagina to a congregation of phalluses. ${ }^{47}$ The scene of scavenging by dogs is a reference to kusōzu (and the depiction of animals aroused by viewing human "sexuality" recalls shunga motifs), while both pictures reference Buddhist practices. Seiu's more fully developed kusōzu paintings similarly present the disintegration of women's bodies as forms of spectacle and as sexual assaults, and his work is an important ex-

46 I use Max Moerman's description of mitate-e as a form of intervisuality. D. Max Moerman, "Dying Like the Buddha: Intervisuality and the Cultic Image," Impressions: The Journal of the Japanese Art Society of America 29 (2007-08): 26.

47 Itō Seiu, Yasuda Korekushon 5: Rongo tsūkai Jigoku no onna (Tokyo: Ginza shokan, 1930), n.p. 
ample of the way in which $k u s \bar{z} z u$, already associated with necrophilia, ${ }^{48}$ merged with the violent, sexual imagery of eroguro.

Rakujō 落城 (Fallen Castle; hereafter Fallen Castle; figure 2) is a hanging-scroll painting of a sadistic scene of female torture, likely from around the 195 os. $^{49}$ It appears to parody a type of Shuten dōji 酒吞童子, a demon known for killing and eating noblewomen, painting that had begun around 1522 with the rendition of the theme by Kanō Motonobu 狩野元信 (1476-1559). ${ }^{50}$ In this famous tale, Raikō 頼光 (Minamoto no Yorimitsu 源頼光, 948?-1021) and his warriors save kidnapped daughters of noble families from the eponymous cannibalistic demon. Keller Kimbrough has suggested that the charnel scene introduced in Motonobu's work was understood by its Edo-period audience as a kind of kusōzu. ${ }^{51}$ Seiu's painting shows five warriors and their leader in a rocky outcrop. A castle hovers in the misty background, and the middle ground is occupied by women in progressive states of undress, roped to trees and rocks. Instead of saving the women, the warriors are thrashing, stabbing, and sexually assaulting them (figure 3). In the lower register a bleeding and bloated corpse lies in the ravine, being consumed by dogs and observed by one of the warriors. Here, several of the most gruesome stages of fujōkan are combined, and the contemplator is a non-monastic. The explicit inclusion of the kusōzu scene in Seiu's apparent parody of Shuten dōji would support Kimbrough's proposal, but it also demonstrates the development of the reception of this genre: it has slipped into the genre of eroguro. In fact, Fallen Castle can in its entirety be considered a mitate-e rendering of $k u s \bar{o} z u$, where the gradual exposure of the living female bodies from their clothing replaces the disintegration of the dead body, where the males carry out a purposeful destruction that is presented as the inevitable work of nature in $k u s \bar{o} z u$, and where the contemplator of the (final) corpse is non-monastic, and

48 See, for example, the tale of Rājadatta in the commentary to the Theragāthā. See Wilson's discussion in "The Female Body as a Source of Horror and Insight in Post-Ashokan Indian Buddhism," 86.

49 In the collection of Tarō Fukutomi. A photograph is published in Geijutsu shinchō, April 1995, 14, with a detail of it on page 15

50 Kept in the Suntory Museum of Art in Tokyo.

51 Keller Kimbrough, "Sacred Charnel Visions: Painting the Dead in Illustrated Scrolls of The Demon Shuten Dōji," in Japanese Visual Culture: Performance, Media, and Text, eds. Kenji Kobayashi, Maori Saitō, and Haruo Shirane (Tokyo: National Institute of Japanese Literature, 2013), 38-40.

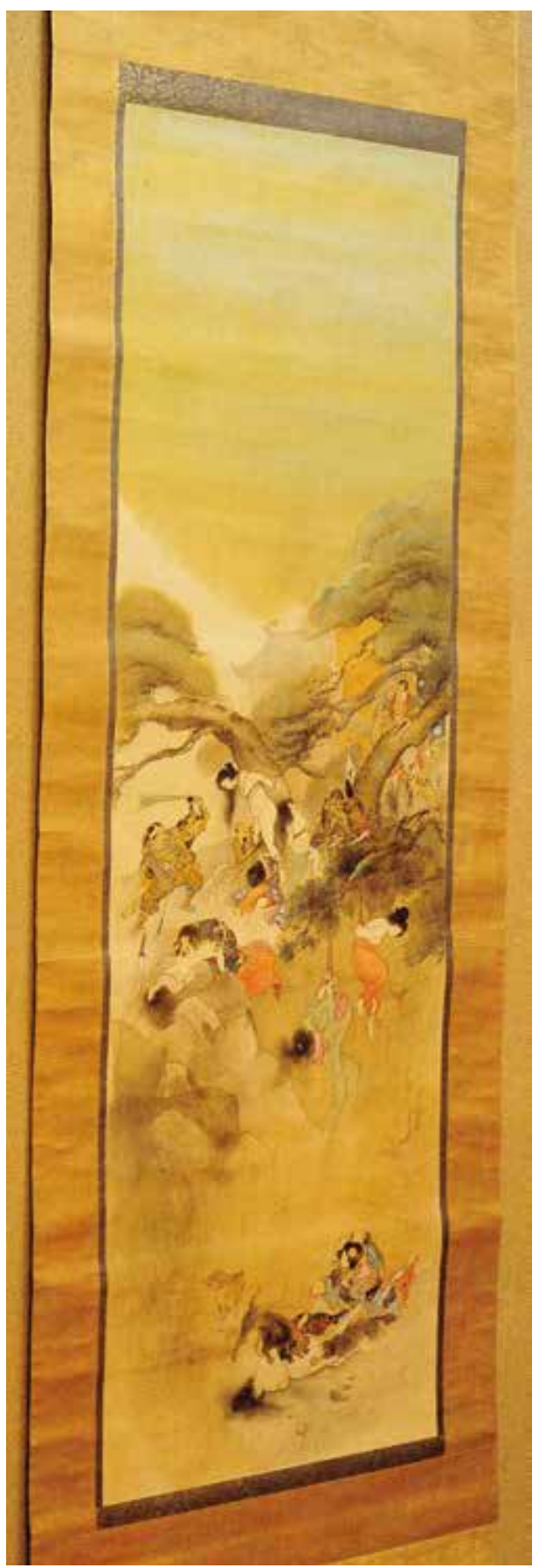

Figure 2. Itō Seiu. Rakujō 落城 (Fallen Castle). Ca. 1950. H. 129.5cm, w. $42.4 \mathrm{~cm}$. Hanging scroll. Ink and color on silk. Tarō Fukutomi Collection. Source: Yamakawa Midori, ed., Geijutsu shinchō (April 1995). 14. With permission of Tarō Fukutomi and Geijutsu shinchō. 


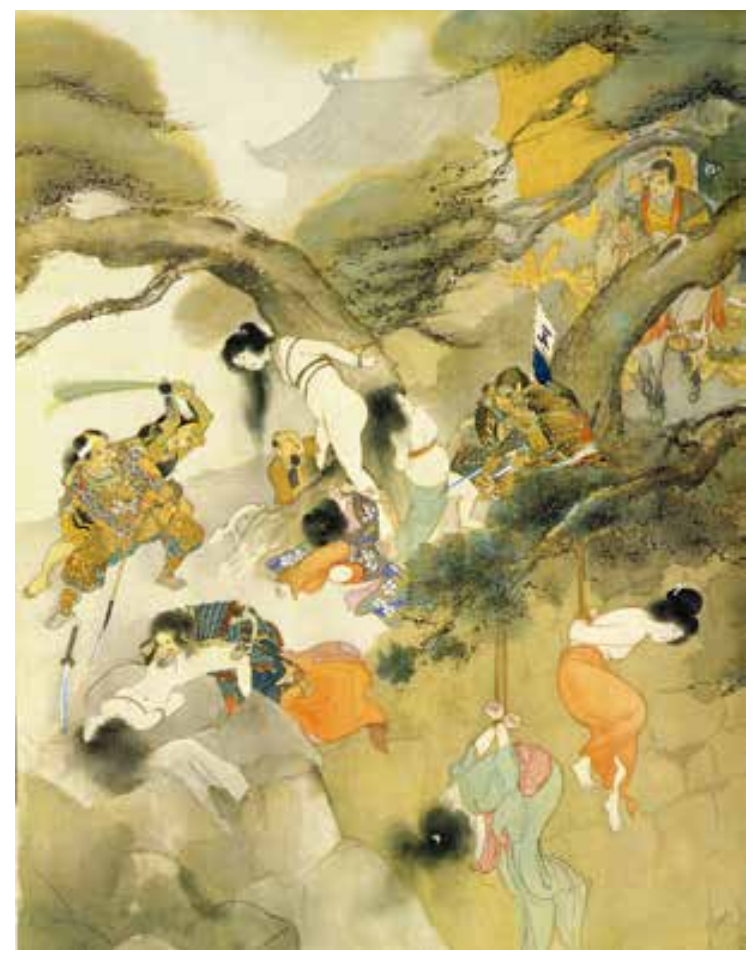

Figure 3. Itō Seiu. Rakujō (detail). Tarō Fukutomi Collection. Source: Yamakawa Midori, ed., Geijutsu shinchō (April 1995), 15. With permission of Tarō Fukutomi and Geijutsu shinchō.

visibly as rapacious as the dogs that accompany him.

Seiu was plainly interested in kusōzu: a complete series appears on one page in Bijin ranbu 美人乱舞 (Beautiful Women Dancing Wildly), his 1932 collection (figure 4). The female figures are lightly sketched in ink and blue color, and summarily rendered in terms of iconography. A gradual bloating indicates the progression but no image of the rotting and opening of the body is included, and while a single crow stands for the consumption scene, instead of pecking at the fleshy body it perches by the totally disintegrated skeleton. Two passages that describe the meaning of the genre according to the cavalier artist are embedded into the sketch:

There is a [type of] picture called a kusōkan that depicts the appearance in death of Ono no Koma-

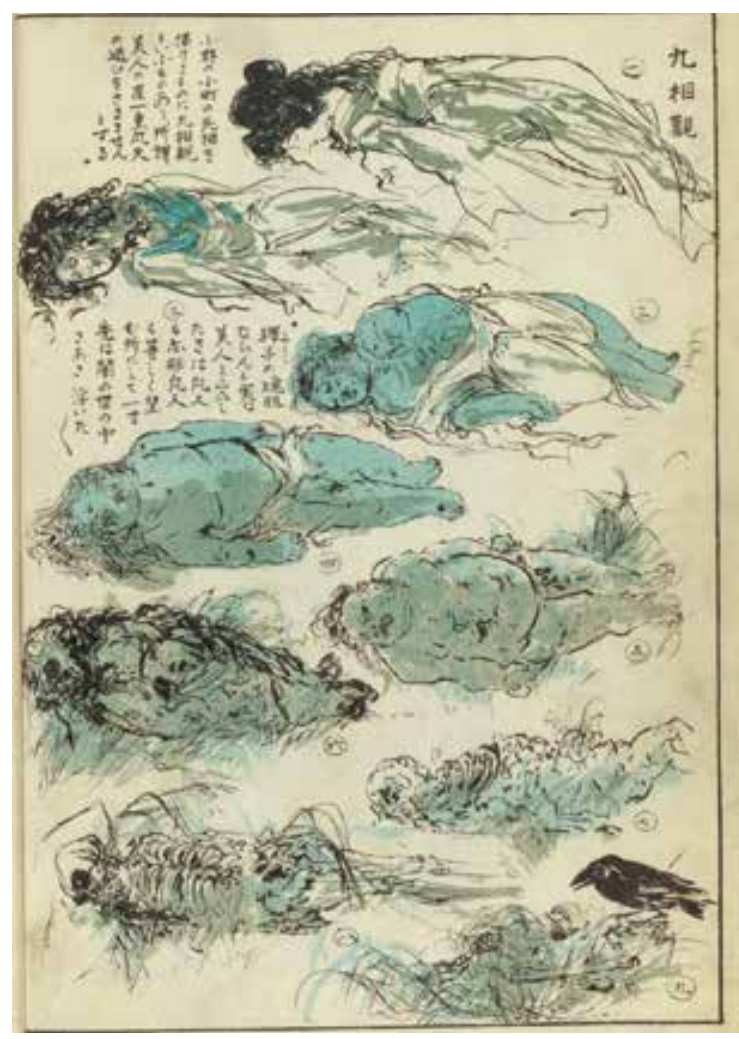

Figure 4. Itō Seiu. Kusōkan 九相観 (View of the Nine Stages). 1932. H. $26 \mathrm{~cm}$. Source: National Diet Library Digital Collection, http://dl.ndl. go.jp/info:ndljp/pid/1177907 (last accessed February 28, 2017).

\begin{abstract}
chi. ${ }^{52}$ It was the motive of Sākyamuni [Buddha] to awaken ordinary people to the skin-deep beauty of so-called beautiful women. But generally speaking, those (both stupid and intelligent) who look just want to XXXX those [beautiful] women. Hey, let's just live - since we can't guess the future! $!^{53}$
\end{abstract}

The kusōzu scene of scavenging/consumption (tansō 噉 相) appears in another painting (figure 5). It is my opinion that this painting is, in its entirety, kusōzu mitate-e, though it has never been classified as such. It is part of a set that was commissioned around 1951 by Matsui

52 The ninth-century poet famed for her beauty with whose identity the kusōzu figure came to be associated by the early thirteenth century. See Chin, "The Gender of Buddhist Truth," 296-306.

53 In the original text, two triangles appear to connote "intercourse," which I translate as four Xs. 


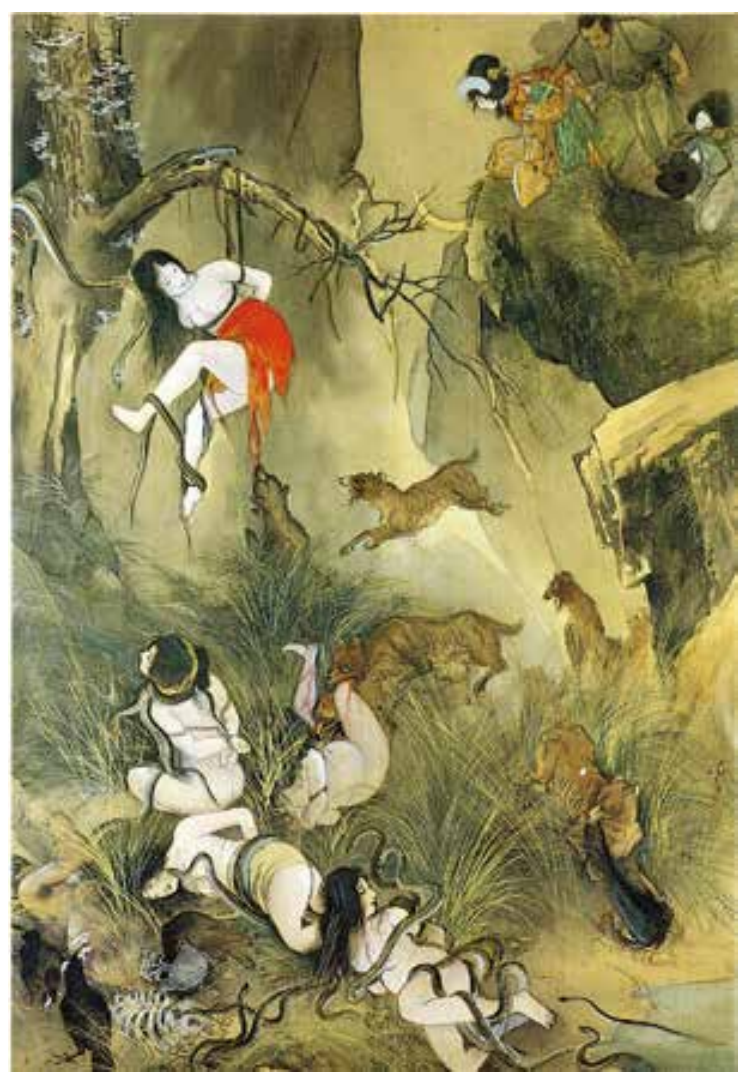

Figure 5. Itō Seiu. Shimabara no ran 島原の乱 (The Shimabara Rebel(ion). Ca. 1950. Dimensions unknown. Hanging scroll. Ink and color on silk. Ryōsenji, Shimoda, Izu. With permission of Ryōsenji.

Daishū, then head priest of Nichiren-sect temple Ryōsenji 了仙寺, on the Izu peninsula. He had requested mitate pictures from Seiu, asking the artist to depict hell as "this world." ${ }^{54}$ Ryōsenji also keeps as hibutsu 秘 亿 (secret Buddhist works) Seiu’s jigoku-e 地獄絵 (pictures of hell). Jigoku-e are a standard type of didactic Buddhist painting, but Seiu's pictures specifically show scenes of torture of women. The text accompanying the work is a moral declaration on the depicted depravities that, it claims, occurred during the 1637-38 Shimabara

54 Matsui Daei, present head priest of Ryōsenji. Interview by author, Ryōsenji, Izu, August 3, 2014. Matsui had a personal connection with Seiu through his wife's hometown temple parish in Chiba, and the relationship between the two is attested by a conversation between them in the 1951 inaugural issue of Amatoria アマト リア magazine, an eroguro publication.
Rebellion. The painting bears the delicate liveliness of stroke that characterizes Seiu's work, the skilled portrayal of contorted bodies, as well as attention to background detail. It is in the same vein as Fallen Castle: the scene is a craggy wasteland, it purports to be a depiction of a war atrocity, and women are shown hanging or fallen from trees, attacked by birds and dogs, and here, by snakes as well. A male is portrayed as the perpetrator of violence. There are nine female bodies in total, surely parodying the nine stages of disintegration. They are arranged as fully dressed in the upper right in gorgeous kimono with hair done up in the shimadamage 島田髹 Edo-period topknot style that Seiu favored, through stages of bondage to a tree branch in the midleft section, to several prostrate states in partial or complete nakedness. One woman is subjected to a biting dog between her legs, echoing the depiction in Fallen Castle of forced cunnilingus by a warrior; both recall the Shōjūraigōji kusōzu as well as the consumption of female bodies in Shuten dōji by the unwary warriors, and the above-mentioned depiction of necrophilia. The line of women zigzags down the scroll ending at bottom left, where a corpse scavenged by crows and dogs lies. Seiu probably saw no contradiction in selecting parts of kusōzu to arrange into his works; however, he was clearly aware of the Buddhist connotations of the genre, as his kusōkan text shows, and since this is one of a set of ten paintings of women being tortured in different ways it seems highly probable that he conceived the set itself as a grand-scale $k u s o \overline{z u}$. One anomalous painting in the set, a rather simple picture of an oiran 花鬼 courtesan, supports this suggestion. It likely opened the series, just as a living beauty sometimes began a kusōzu series, heightening by contrast the impending disintegration.

Although production of kusōzu indeed seems to have decreased, these examples may be considered evidence of the resilience rather than the withering of a subject that was officially discarded but survived in the subterranean domain of ephemeral and subversive media, including that of Buddhist temples, continuing to exert influence on the imagination. What does seem clear is that kusōzu were not being produced for ostensibly unequivocal "Buddhist" purposes (such as meditation or for conversion/edification narratives). The factors that Yamamoto proposed as related to $k u s \bar{o} z u$ during and after the Meiji period are persuasive: the gothic/grotesque novelists, the beautification of (female) death, particularly suicide, and war experience. All three of these are concerned with 
notions and aesthetics of dismemberment that are contextually particular in Japanese modern visual culture. Other linked phenomena are at play here: the adoption of the western nude and the development of anatomical studies, inherent in which too are issues of dismemberment. Moving forward into the early twenty-first century, while painter Yamaguchi Akira 山口晃 (b. 1969), manga artist Masaki Hidehisa 正木秀尚 (b. 1964), and photographer Fujiwara Shinya 藤原新也 (b. 1944) have taken up the subject matter, Matsui's large-scale project occupies central place in what is seen as its revival. But as I have suggested, this is not a revival of medieval or even pre-modern work; it is largely that of the modern period, and it is a continuity.

\section{The Nude, the Classical, and the Grotesque}

Matsui's kusōzu bodies are profoundly different from their pre-modern predecessors: they are idealized Western-style nudes. She bases these on studies of herself, live models, and European waxwork anatomical dolls. As mentioned above, in the Meiji period, the classical body - the Western nude - was adopted by painters and sculptors in the Japanese academy. However, some of its connotations were apparently exorcised in the transition. Satō Dōshin notes that, for example, "the basic premise of Western art, which did not exist in Japan, was that a 'human' figure without a stitch of clothing on was also a 'divine' figure," but he asserts that the genre of the nude was transplanted to Japan "without most of its original religious and humanistic baggage." ${ }^{55}$ Such painted nudes and sculptures were ideal, classical types. In fact, since some of the religious connotations of the "Western" naked body themselves changed when rendered as an anatomical model, ${ }^{56}$ it may be argued that the classical nude in Japanese art had in some ways, by virtue of discarding the "divine," something fundamentally more in common with these. In Japan, previous and contemporary endeavors at ren-

\footnotetext{
55 Dōshin Satō, Modern Japanese Art and the Meiji State: The Politics of Beauty (Los Angeles: The Getty Research Institute 2011), 264-65. However, in later eroguro, especially in its postwar phase, the nude is imbued with religious meaning, particularly that of martyrdom and punishment.

56 The dead body could now be opened, observed, mapped, and
} had no supernatural element. dering the unclothed human body were "in the realm of the particular and the sensual," as Jaqueline Berndt puts it, ${ }^{57}$ such as those, indeed, of anatomical illustrations and models, the sensationally revealed bodies of temple or street fair spectacles, and "living dolls" ( $i k i$ ningyo 生き人形) (all three of which were often one and the same). The ideal nude was a rejection of the realistic flaws of the human body.

There are two principal ways in which the early Japanese nude is (counter-intuitively) connected with these two "lower" culture renderings, and in fact more fundamentally to the grotesque. One way is a result of the above-mentioned attempt to purge the "divine" aspects and the other is a result of some of the types of European influences in the works of Meiji- and Taishōera sculptors and painters. What we see here, again, is that Matsui's work is not only or even predominantly a product of a combination of two distinct "Western" and "Japanese" cultures. It is a product of the early-twentieth-century formation of identity, the negotiations with European culture that this involved, and a subculture that was produced from it. Setting aside for a moment its cultural specificity, Mary Russo's comparison of the classical and the grotesque bodies in European culture is relevant here. She writes: ${ }^{58}$
The images of the grotesque body are precisely those which are abjected from the bodily canons of classical aesthetics. The classical body is tran- scendent and monumental, closed, static, self-con- tained, symmetrical, and sleek; it is identified with the "high" or official culture of the Renaissance and later, with the rationality, individualism, and normalizing aspirations of the bourgeoisie. The grotesque body is open, protruding, irregular, se- creting, multiple, and changing, and it is identified with non-official "low" culture. . $^{59}$

The (official) fading out of the "kusōzu body," if it can be so termed, is perhaps unsurprising then, because the

57 Jaqueline Berndt, "Nationally Naked? The Female Nude in Jap anese Oil Painting and Posters 1890s-1920s," in Performing the Nation: Gender, Politics, and the Visual Arts of China and Japan 1880-1940, ed. Doris Croissant et al. (Leiden: Brill, 2008), 327.

58 It is also useful in comparing with the "closed" body of the viewer that is constituted by the "open" body of the kusōzu subject, which Wilson described.

59 Mary J. Russo, The Female Grotesque: Risk, Excess and Modernity (New York: Routledge, 1995), 8. 
original "grotesque" is anti-classical and anti-ideal. The term itself originally derived from "grotto-esque" or "grottesco" and its origins are found in Nero's Domus Aurea ("Golden Palace"), an imperial Roman villa and its rooms-(mis-)perceived as "grottoes" because underground-excavated in Rome during the fifteenth century. The structure was originally vast, labyrinthine, and filled with lavish manmade land- and waterscapes. "Grotesque" denoted, in the Renaissance, the style of Fabullus's decorative wall and ceiling frescoes that were discovered there, a major feature of which was the fantastical, playful, and ornate fusion of human body parts with those of plants, birds, animals, fish, cameos, and architectural motifs, or hybrid entities such as hippogriffs and winged Victories. Such bodies contrasted with the classical, perfect, whole and bounded body. This "grottesco" appealed to Renaissance artists (and later to Neoclassicists of the late eighteenth century) and was mainly employed in architectural ornamentation, frescoes, framework, and illuminated manuscripts, its application indicating it was materially marginal, and borderline in form, content, and function, just as its place of origin was submerged and otherworldly.

The original palace and its decoration has seemingly little to do with the later uses of the term "grotesque": Bakhtin's carnivalesque, unbounded body, Kristeva's abject, or Ruskin's complex elaboration of the aesthetic (indeed, the term has come to umbrella a variety of expressive modalities). It may be suggested, however, that the grotesque as signifier of monstrosity is related as much to the unnatural fusions found in the "grotto" interiors as to the position of the grottos themselves. Grotesque monsters are, after all, inhabitants that emerge from dark, sinister, buried places. For example, both (Gothic) architectural ruin and grotto are related to the genre of horror, for they are architectural or natural bodies that contain buried objects and they stand in for broken or violated bodies, depending in large part for their atmospheric power on their evocation of a former lively and animated unity. Kusōzu are an exceptionally apposite example of the grotesque in their many mutually reinforcing ways, including the former animation their bodies indicate, and the open body that fuses with nature. Despite the reasonable assumption, however, that kusozzu bodies faded out with the introduction of the Western classical body and its accompanying ideals of rationality and modernity, it can be argued that in fact the grotesque came to be articulated by the classical. How is this so? In common with the grotesque, the classical body itself with its perfect human bodily proportions, which had exerted a strong influence on Renaissance artists, depended upon objects that had been disinterred from various sites. It was in many ways known through the buried and the ruined. When these ideal bodies came up out of the ground they were often missing arms or a head; they might have been nothing but torsos. Laocoön and the Belvedere Torso are representative examples. But there is an important distinction between how Renaissance artists and nineteenth-century European artists treated them. The Renaissance artists, generally speaking, did not emulate and employ them as dismembered. They used them as parts that hinted at a whole that could be reconstructed: a whole that represented human bodily perfection. And that body was part of the city of ancient Rome that was also itself being studied and mentally reconstructed through scrutiny of its ruins by Renaissance artists and scholars. But the nineteenth-century artists celebrated the forms in their truncated and broken states, and it was the works of these, most notably of Rodin, from which a number of Japanese artists training in Western sculpture studied. ${ }^{60}$ In the late nineteenth and early twentieth centuries, Aristede Maillol (1861-1944), Antoine Bourdelle (1861-1929), and Vincenzo Ragusa (1841-1927), for example, provided inspiration to sculptors like Takamura Kōtarō 高村光太郎 (1883-1956), Ogiwara Morie 荻原守衛 (Rokuzan 碌山, 1879-1910), and Tobari Kogan 戸張孤雁 (1882-1927), who all produced torsos and headless or limbless female bodies. It can be suggested that, similarly, one reason the grotesque body returns (or can be re-identified) in Japanese Meiji and post-Meiji visual culture in its new classically influenced bodies is because when this classical body is introduced into Japanese art in the Meiji period ${ }^{61}$ it is already a period in Europe in which a broken body, especially a nude one, is fetishized.

To say that the fetishization of body parts was a dominant influence on modern Japanese sculptors would be a vast and simplistic overstatement. It can be suggested, however, that the concomitant emergence of eroguro, which I will address below, provided it a sub-

\footnotetext{
60 See Tanigawa Atsushi, Haikyo no bigaku (Tokyo: Shūseisha, 2003), 19-29.

61 The classical body in visual art and Western art had been available in Japan with varying levels of accessibility from the fifteenth century on. Here I am focusing on art that was officially supported in the Meiji academy.
} 
cultural channel. If this is so, one can also suggest that in late-nineteenth- and early-twentieth-century Japan the classical, ideal body was itself, paradoxically, monstrous and grotesque. This means that Japan's grotesque differs significantly from its Western predecessor, and this was produced through a confluence of other literary, visual, and historical phenomena. Additionally, it was in the late eighteenth and nineteenth centuries that a preoccupation with the female corpse in visual culture became evident in Europe in relation to developments in science and medicine. ${ }^{62}$ There is a bifurcation when it comes to how this visual vocabulary of the broken body developed: we find that the kusōzu, as part of a grotesque aesthetic, is articulated in a twilight language, while the dismembered body becomes part of official visual culture (as well as part of subculture). It is precisely these reappearances, and the double cultural positioning in the late nineteenth and early twentieth centuries that inform Matsui's work and to which she succeeds.

\section{Kusōzu and the Erotic-Grotesque}

Through visual analysis and elaboration of context these strands of influence can be teased out of Matsui's work. The binding theme of Matsui's kuzōsu series is suicide and it informs a number of her other paintings, such as those that depict Aokigahara 青木ヶ原, a real forest notorious as a site of suicide. Its role in her kuzōsu series is less obvious and we must turn to her own written commentaries to find the intended meaning: the series is illustrative of a series of suicides, each for a different reason. There are also motifs of pregnancy, anatomical dissection, artificial landscape, and Christian figures. These, along with the interest in suicide, differentiate her work from premodern $k u z o \overline{s u}$, and contribute to a visual statement of boundary transgression that is at root grotesque.

Before giving specific examples, a summary of the development of this aesthetic is necessary. Eroguro nansensu エログロナンセンス (the “nansensu,” or "nonsense," component has today been more or less discarded) is a term used to describe a mass-culture

62 Ludmilla Jordanova, Sexual Visions: Images of Gender in Science and Medicine between the Eighteenth and Twentieth Centuries (Wisconsin: The University of Wisconsin Press, 1989), 98 decadent artistic and literary sensibility that originated around the late 1920 s and early ' 30 s in Japan, the "interwar period." Described as "the prewar, bourgeois cultural phenomenon that devoted itself to explorations of the deviant, the bizarre, and the ridiculous," ${ }^{63}$ its subject matter included the first Japanese forays into the genres of detective and mystery fiction, as well as pornography, news, graphic art often presented as montage, and articles on sexology and anthropology. Elements of these were often melded together. The word gurotesuku グロテスク held similarities to its western counterpart. In the first issue in 1929 of the popular magazine Ryōki gaho 猟奇画報 (Curiosity-Hunting Pictorial), which published this sort of material, the characters 好色的 (kōshokuteki or erotic) and 怪奇的 (kaikiteki, meaning difficult to explain or repulsive in appearance), and written as a compound, are glossed in katakana script as eroch$i k k u$ gurotesuku. ${ }^{64}$ Ryōki ("curiosity-hunting") itself is described in a 1931 dictionary of new slang as often used with erotic-grotesque connotations. As a term, eroguro was closely related to the ryōki sensibility: both focused on "trash" literature and art concerned with what was conceived of as perverse and improper desire, but mixed too with themes of detection and mystery. The work of author Edogawa Rampo exemplified the eroguro. Leftist intellectuals of the 1920 s and ' 30 s considered it an effect of urban modernity, providing ever-higher and stranger stimulation to the bored urban dweller/consumer. It is possible to trace the sensibility, though not the term that later describes it, back to the muzan-e 無残絵 ("pictures of cruelty") of Tsukioka Yoshitoshi, previously mentioned, and before him to Utagawa Kuniyoshi 歌川国芳 (17981861). Suzuki Sadami flags the origins somewhere between these designations, in the period immediately following the Russo-Japanese War of $1904-05 .{ }^{65} \mathrm{Greg}$ -

63 Jim Reichart, "Deviance and Social Darwinism in Edogawa Rampo's Erotic-Grotesque Thriller, Kotō no oni," Journal of Japanese Studies 27 (2001): 114. See Silverberg for the social and cultural background to this phenomenon in the 1920 s and '30s. Miriam Silverberg, Erotic Grotesque Nonsense: The Mass Culture of Japanese Modern Times (Berkeley and Los Angeles: University of California Press, 2007).

64 See Jeffrey Angles, "Seeking the Strange: Ryōki and the Navigation of Normality in Interwar Japan," Monumenta Nipponica 63. no. 1 (2008): 105.

65 Suzuki Sadami, "Ero, guro, nansensu no keifu," in Ranpo no jidai: Shōwa ero, guro, nansensu, ed. Yonezawa Yoshihiro (Tokyo: Heibonsha, 1995), 10 
ory Pflugfelder's definition of the three-part term is useful: ${ }^{66}$

Each of the three elements implied a perversion, as it were, of conventional values. The celebration of the "erotic" (ero) in its myriad forms constituted a rejection of the Meiji dictum that sexuality was unsuited for public display or representation unless it conformed to the narrow standards of "civilized morality." The elevation of the "grotesque" (guro) betrayed a similar disregard for prevailing esthetic codes, with their focus on traditional canons of beauty and concealment of the seamier sides of existence. Finally, the valorization of the "nonsensical" (nansensu) signaled a discontent with the constraining nature of received moral and epistemological certitudes. ${ }^{67}$

As eroguro developed away from a Taishō-period efflorescence, especially in its post-war manifestations, it grew dark, perverse, and increasingly centered on eroticized boundary violation, dismemberment, fusion with nature, and simulacra, and it was expressed in many ways in nikutai bungaku 肉体文学 ("flesh literature"). The latter, as Douglas Slaymaker and others have shown, was conceived in its time as an expression of (often sexual) bodily liberation in defiance of the kokutai 国体 (body politic) to which its proponents felt the Japanese (male) body had been sacrificed during the Pacific War. But it inevitably oppressed the female body in its own liberation. ${ }^{68}$ In many ways the manifestation of eroguro in the post-war period was a resurgence of its earlier character, as Suzuki indicates, and its appearance in both periods was as resistance to an imposed morality ${ }^{69}$ In both periods, it was clearly an expression of resistance to bodily (particularly sexual) norms, but should not be considered an expression of the liberation of "natural" sexuality. Indeed, commentators, his-

66 Which, incidentally, maps quite well onto Bataille's definition of the "informe" that was an important part of his theories on disgust.

67 Gregory M. Pflugfelder, Cartographies of Desire: Male-Male Sexuality in Japanese Discourse 1600-1950 (Berkeley: University of California Press, 2000), 290. Silverberg locates the "guro" in marginalized groups of the time such as Asakusa's vagrants. See Silverberg, Erotic Grotesque Nonsense.

68 Douglas Slaymaker, The Body in Postwar Fiction: Japanese Fiction after the War (New York: Routledge, 2004).

69 Suzuki, "Ero, guro, nansensu no keifu," 10. torians included, who claim it to be so dehistoricize it and obscure the constructions commandeered by the genre. The present-day manifestation of eroguro as it has developed in Japan (and elsewhere) since the end of the Pacific War might be described in English by the compounds porn-horror or torture-porn.

A perfect example of the combination of suicide, classical body, and artificial landscape is found in Tanizaki Jun'ichirō's fake Nero palace in his short story Konjiki no shi 金色の死 (The Golden Death) of 1914. The story was based on The Domain of Arnheim (1847) by Edgar Allan Poe, whose gothic and grotesque work was an influence on Tanizaki, and both of which in turn fed into Edogawa Rampo's 1926 Panoramatō kitan パノラマ島奇談 (Strange Tale of Panorama Island). Rampo revered both writers. All three stories feature constructed landscapes that are at once astonishingly beautiful and horrifying; the aesthete inhabitants of those in Tanizaki and Rampo's works both die in glorious suicides, at the heights of ecstasy in their artificial paradises. These two tales seem to draw on the Domus Aurea as the constructed and palatial paradise par excellence; Rampo's paradise was partly populated by people fused surgically with animals: the Roman decorative fancies come to life. ${ }^{70}$ Tanizaki's mansion is filled with replicas of famous works and monuments of Western culture, statues of nude women, centaurs, and at its center, Rodin's Eternal Idol. ${ }^{71}$

Tanizaki's production of sadomasochism-themed fiction makes him much a part of this evolving subculture. Tanizaki was also interested in $k u s o \bar{z} u$, and he depicted the corpse meditation in his novella, mentioned briefly above, Shōsho Shigemoto no haha, a 1949 work written in the Occupation period (1945-52) that explores a number of eroguro obsessions. Here, fujōkan is performed by a layman (again, the monastic figure, implied or explicit, is absent) who visits a "charnel ground on the edge of a moor," 72 the end point of a journey from the center of town through increasingly ruined residences to a peripheral wasteland that is described

70 Maruo Suehiro, whose manga work epitomizes eroguro today, pictorialized Rampo's vision. Maruo Suehiro, Panoramatō kidan (Tokyo: Kadokawa, 2008).

71 Tanigawa Atsushi discusses this story, drawing attention to its links with Rampo, Mishima, the body, and suicide. Tanigawa, Haikyo no bigaku, 80-101.

72 Translated by Edward Seidensticker in Donald Keene, Modern Japanese Literature: From 1868 to the Present Day (New York: Grove Press, 1956), 395. 
in sequential, detailed stages, making use of the distance that is conceptually and often visually or literally evoked by kusōzu and necessary to their power. Unlike those ideal monks of the past - the implied audience of kusōzu or practitioner of fujōkan - Tanizaki's character eventually admits he finds no enlightenment, nor can he forget the woman he loved and whose memory he sought to erase through female-corpse contemplation. Before long he loses himself in wine instead of graveyards, and replaces his sutras with poetry. Here, we are once more far removed from the conventional or ideal fujōkan, and in the realm of dark sexual desire.

Exploration of the eroticized dismembered (military) body in Edogawa Rampo's 1929 short story Imomushi 芋虫 (Caterpillar) is also exemplary of the eroguro aesthetic (the disintegrating military body in the short Edgar Allan Poe story, The Man That Was Used Up (1839), doubtless an influence). Reception of Rampo's story during the Pacific War changed and it was banned by Japanese authorities in 1939 for its unpatriotic depiction of a quadriplegic veteran. ${ }^{73}$ Matsui explores a question that occupies these two writers in her "Yaya karui akkon wa kōsaku shite mōjō ni hashiru" no tame no shasei fuwakezu: Shishi setsudan 『やや かるい圧痕は交錯して網状に走る』のための写 生腑分図：四肢切断 (Sketch for Light Indentations Mingle and Run in All Directions, Anatomy Chart: All Four Limbs Cut Off, 2008): $:{ }^{74}$ where is humanity located in the body? The only sign of it in the remaining collection of organs is a section of nose. Toward the end of the Allied Occupation, and with changes in censorship laws, mutilated bodies and even fetishistic images of seppuku 切腹 (ritual self-disembowelment) were depicted in early S\&M magazines, but the cast was an all-female one. One figure whose work features in early issues was Seiu, previously discussed. Seiu's intense reworking of Yoshitoshi's Ōshū Adachigahara hitotsu no ie no zu 奥州安達が原ひとつの家の㘡 (The Lonely House at Adachigahara in Ōshū) - a reworking that remains renowned as instrumental in the development of the visual culture of rope bondage and S\&M, and to which I return below-is testament to his admiration. Rampo was a fan of Yoshitoshi too, and knew his and Seiu's work. The Edo-era gothic horror expressed in the

73 Wakamatsu Kōji's 2010 Kyatapirāキャタピラー based on Rampo's story was intended as an explicit antiwar statement. The story was made into a manga by Maruo Suehiro in 2009. 74 Matsui, Becoming Friends with All the Children in the World, 98. works of Yoshitoshi was revived in the post-war period: films with supernatural themes like Ugetsu monogatari 雨月物語 (Tales of Moonlight and Rain, 1953) and Yabu no naka no kuroneko 數の中の黒猫 (The Black Cat in the Grove, 1968) were implicit critiques of war and related gender issues. It may be that the literal ruination of much of Japan, particularly the structures and infrastructure of its urban spaces, as well as the historically military connotations of seppuku contributed to the darker eroguro of this period. Full exploration of this suggestion, however, is well beyond the parameters of this paper. More to my interest here is that Matsui's work indicates a wide network of associations with eroguro, an aesthetic that resonates with kusōzu as a "Buddhist" genre, and through which the kusōzu of Seiu and Matsui find expression.

\section{Matsui's Kusōzu Series}

The previous extended exploration into the history of kusōzu, the socio-historical position and literary examples of eroguro, and the introduction to Seiu's times and his kusōzu were necessary for identifying Matsui's precursors and her interaction with them. As mentioned, the fourteenth-century Picture Scroll of the Nine Stages is frequently cited as Matsui's model. Spectators are notably absent, in contrast to some premodern versions we have considered and to Seiu's mitate-e. Also in contrast to the latter's proclivity to narrativize kusōzu, Matsui returns to the format of a lone body presented in distinct stages. I will draw out some of the ways in which her work resembles and diverges from the Picture Scroll of the Nine Stages, paying special attention to the siting and portrayal of the body, the flowers and animals depicted with it, the proposed audience, and the explanations provided by Matsui herself. I will use as supplementary material several other of her works that she does not include in her kusōzu series: Shükyoku ni aru itai no sanzai 終極にある異体の散在 (Scattered Deformities in the End, 2007; figure 6), ${ }^{75} K \bar{o} s \bar{o}$ 構想 (Conception, 2009; figure 7), ${ }^{76}$ and Inkoku sareta shishi no saidan 陰刻された四肢の祭壇 (Engraved Altar of Limbs, 2007; figure 8), ${ }^{77}$ along with Sakura no shita 


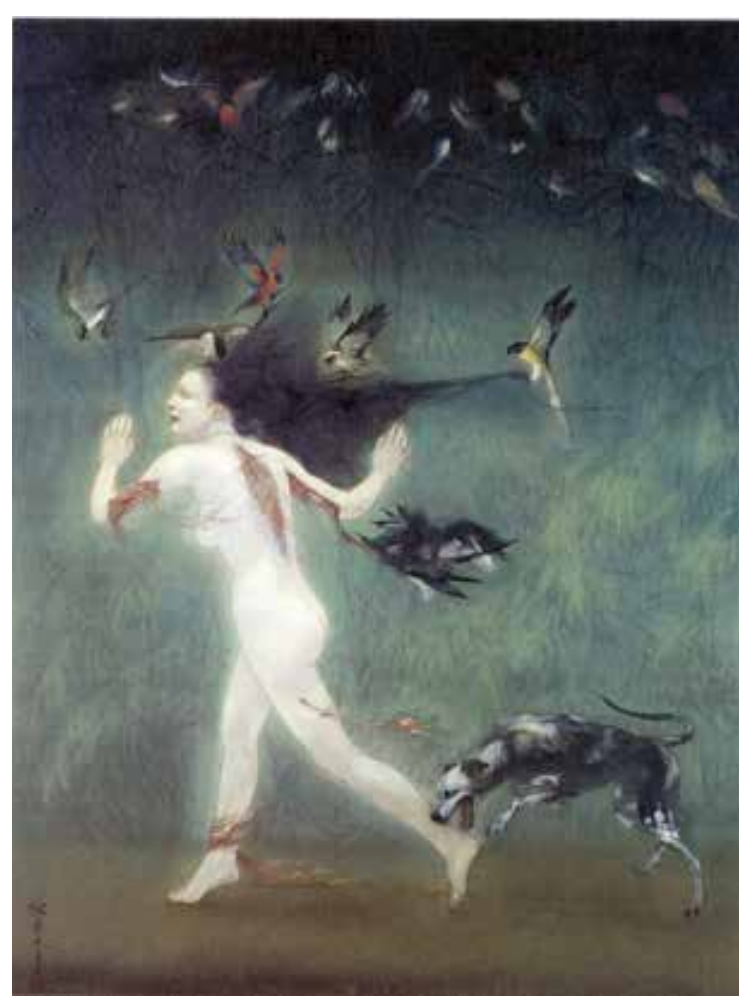

Figure 6. Matsui Fuyuko. Shūkyoku ni aru itai no sanzai 終極にある 異体の散在 (Scattered Deformities in the End). 2007 . H. $124.3 \mathrm{~cm}$, w. $97.4 \mathrm{~cm}$. Hanging Scroll. Color on Silk. Private collection. Source: Matsui, Becoming Friends with All the Children in the World, 166, fig. 102. With permission of Matsui Fuyuko and Éditions Treville.

kyō onna no $z u$ 桜下狂女図 (Insane Woman Under a Cherry Tree, 2005; figure 9) ${ }^{78}$ Matsui's series is not depicted in a single painting; each stage of disintegration is a discrete piece and, as of December 2013, five have been produced, though not in order. ${ }^{79}$ I discuss them in order of production. The earliest of the series, Jōso no jizoku 浄相の持続 (Keeping Up the Pureness, 2004; figure 10), while the resemblance is slight, appears to correspond to the sixth stage (nōransō 膿爛相) of the Kyushu National Museum scroll, mentioned previously. The naked subject is supine and locks milky eyes with

78 Ibid., 128.

79 Yamamoto, Kusōzu o yomu, 240. Matsui intends to complete the series with a tenth piece showing the subject prior to death (Naruyama Akimitsu, Gallery Naruyama. Interview with the author, Tokyo, July 12, 2015).

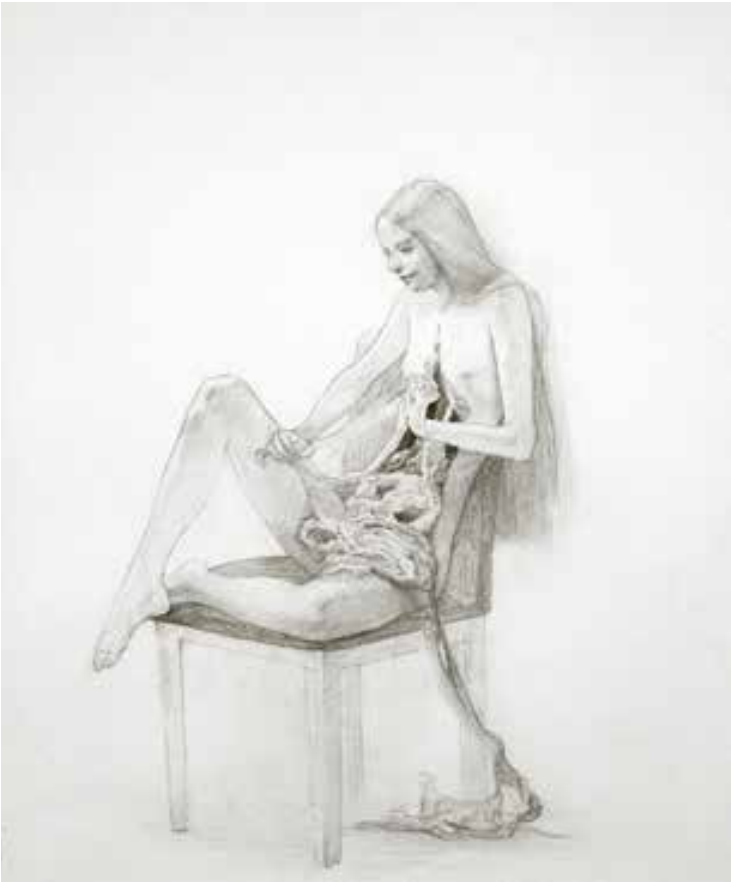

Figure 7. Matsui Fuyuko. Kōsō 構想 (Conception). 2009. H. 53.1cm, w. $46.6 \mathrm{~cm}$. Pencil on paper. Collection of Hamamura Tatsuo. Source: Matsui, Becoming Friends with All the Children in the World, 120, fig 74. With permission of Matsui Fuyuko and Éditions Treville.

the viewer. A dark, smoky pool of black hair spills onto the ground around her head. A flower garden blooms around her jubilantly, an Ophelia-like floral grave. So far, so conventional. But strikingly, the body is sliced open from upper chest to lower abdomen, revealing a neatly stocked cabinet of innards: the unspooled caterpillar-like intestine and dislocated ovaries are positioned outside. Also on exhibit is a fetus, a display that Matsui states is representative of the contrast of "aggressive pride in the womb" and "revealing the source of self-harm," or "a destructive action for the purpose of defense." ${ }^{\prime 0}$ In an interview she explains:

80 Matsui, Becoming Friends with All the Children in the World, 200. 


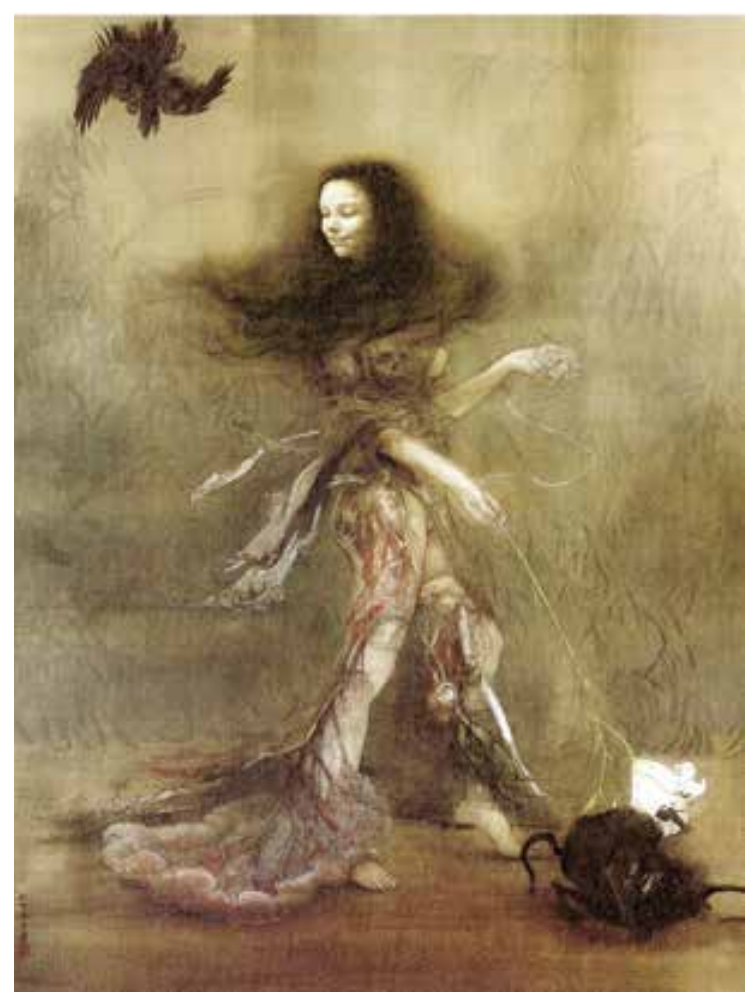

Figure 8. Matsui Fuyuko. Inkoku sareta shishi no saidan 陰刻され た四肢の祭壇 (Engraved Altar of Limbs). 2007. H. $222 \mathrm{~cm}$, w. $172 \mathrm{~cm}$. Hanging scroll. Color on silk. Tokyo University of the Arts. Source: Matsui, Becoming Friends with All the Children in the World, 164, fig 101. With permission of Matsui Fuyuko, Tokyo University of the Arts, and Éditions Treville.

According to anatomical reports, women are inferior to men when it comes to the development of organs other than the uterus .... I decided that I wanted to depict a woman flaunting herself in the form of an objectively viewed, anatomical body. ${ }^{81}$

Yūko Hasegawa, the interviewer, explains that the figure is herself responsible for her cut-open stomach, that the work is also aimed at potential rapists, and that the fear and pain associated with femaleness as victimhood is now a source of strength. In sum, she is a powerfully masochistic figure, rather than the passive kusōzu

81 Yūko Hasegawa, "In the Realm of Hell," http://www.tate.org. uk/context-comment/articles/realm-hell (accessed January 20 2017).

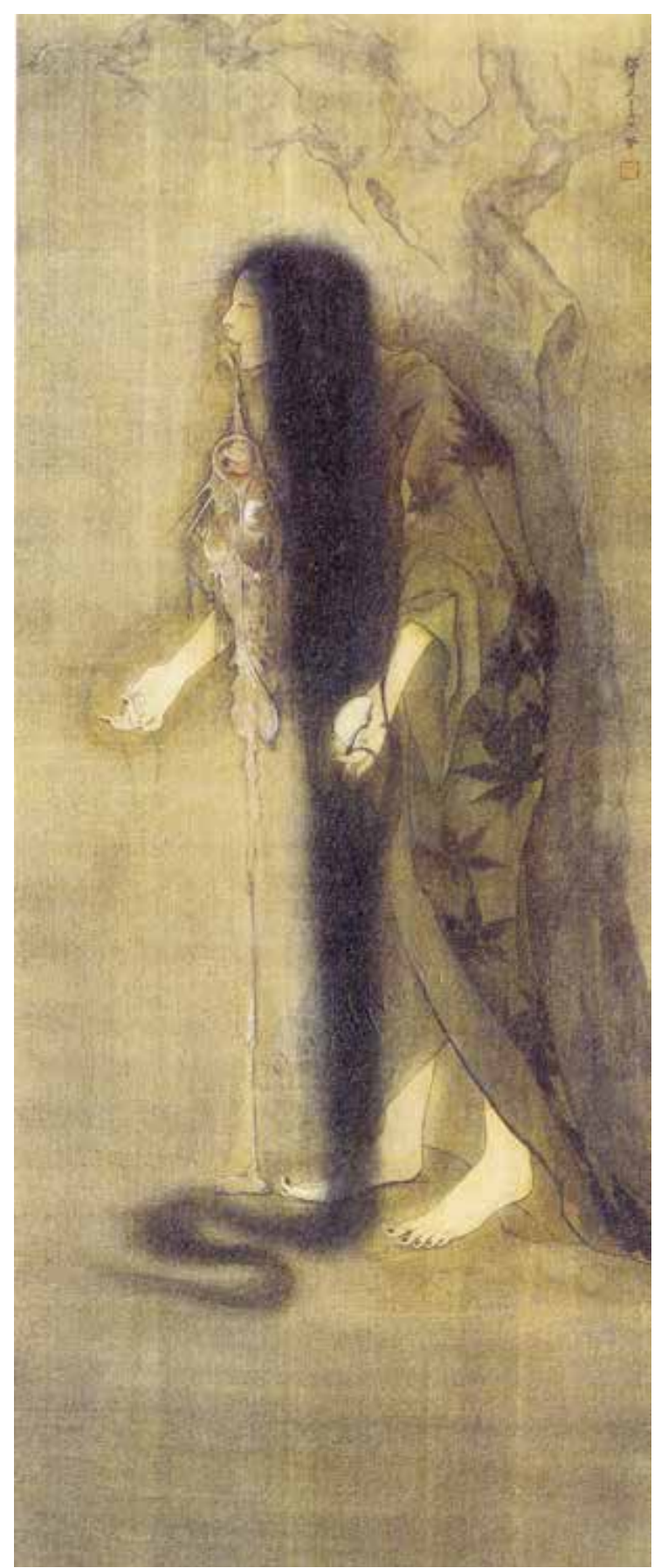

Figure 9. Matsui Fuyuko. Sakura no shita kyōjo zu 桜下狂女図 (Insane Woman Under the Cherry Tree). 2005. H. $131 \mathrm{~cm}$, w. $50.8 \mathrm{~cm}$. Hanging scroll. Color on silk. Private collection. Source: Matsui, Becoming Friends with All the Children in the World, 128, fig. 81. With permission of Matsui Fuyuko and Éditions Treville. 


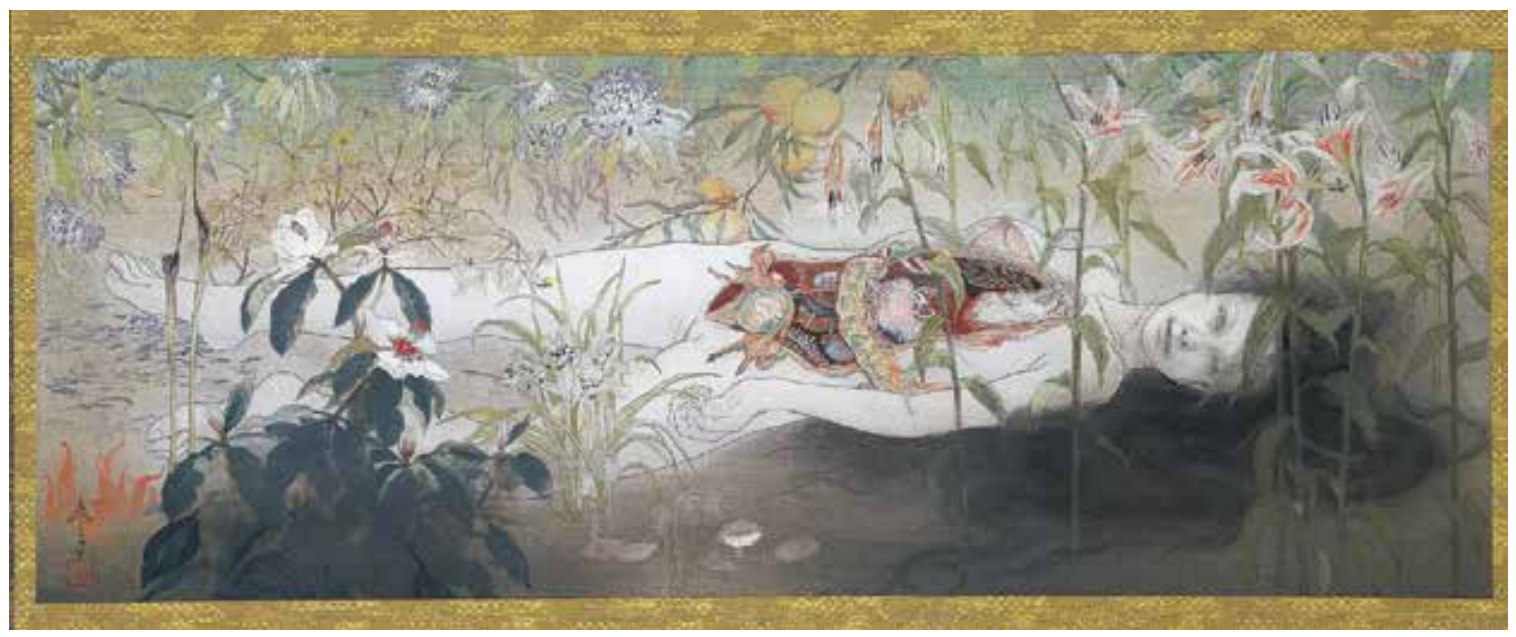

Figure 10. Matsui Fuyuko. Jōsō no jizoku 浄相の持続 (Keeping Up the Pureness). 2004. H. $29.5 \mathrm{~cm}$, w. $79.3 \mathrm{~cm}$. Hanging scroll. Color on silk. Permanent loan to the Hirano Museum of Art. With permission of Matsui Fuyuko and Éditions Treville.

corpse; she has taken her own life in a kind of seppuku in order to proudly display her biological difference and power. The immediate source for the central female figure here is Matsui's drawing of a life model, ${ }^{82}$ possibly combined with self-portrait. Both resemble, in terms of pose, the Kyushu corpse, but in other respects the body markedly differs from the stage of the kusōzu series to which it seems to conform, because the torso is cleanly cut, and is marked by an "exquisite precision" of the like that Edo-period "Dutch Studies" (rangaku 蘭 学) enthusiast Sugita Genpaku 杉田玄白 (1733-1872) admired in the first western medical text he encountered. ${ }^{83}$ The open body is less seppuku imagery and more anatomical model, specifically Clemente Susini's (1754-1814) Anatomical Venuses, and other gynecological waxworks popular in eighteenth-century Europe, ${ }^{84}$ which displayed reproductive organs and fetuses. These in turn bring to mind the dissection drawings of $\mathrm{Da}$

82 Matsui, Becoming Friends with All the Children in the World, 79

83 Shigehisa Kuriyama, "Between Mind and Eye: Japanese Anatomy in the Eighteenth Century," in Paths to Asian Medical Knowledge, eds. Charles Leslie and Allen Young (Berkeley: University of California Press, 1992), 29.

84 See Elizabeth Stephens, Anatomy as Spectacle: Public Exhibitions of the Body from 1700 to the Present (Liverpool: Liverpool University Press, 2011).
Vinci, a major stylistic and technical influence and inspiration for Matsui, as a cursory look at her work attests. The similarity with anatomical models abruptly shifts the viewer away from the kusōzu discarded female corpse as signifier of food for wild birds and beasts and tool of liberation for ascetic practitioners. It moves it instead toward a new signifier of body as tool of anatomical instruction connected to autopsy and dissection: a distinctly modern, western view of and function for the dead body. That Matsui draws on motifs of western art (the classical body, Ophelia, Venus) and of Renaissance art and modernity (Da Vinci, anatomical dissection) is coherent within her oeuvre as a whole and within the scheme of the grotesque she takes up and develops. Like the dismembered classical body, the opened, dissected body too is as grotesque as it is modern. Indeed, the original meaning and aesthetic of "the grotesque" is, at base, hybridity, and hybridity is made possible by cutting, dismembering, and rearranging (fuwake 腑分); this latter term was originally used in Japan to signify anatomical dissection. I will devote the remainder of the discussion to the boundary state that Matsui achieves through the opened bodies that she portrays, the significance of both European and Japanese anatomical models in the portrayals, and the way these models relate to eroguro, through discussion of the rest of her series.

In the second piece in Matsui's series, Narihai no sakeme 成灰の裂目 (Crack in the Ashes, 2006) the body we observed in the first piece is overturned and lies face down on the ground. Similarly spread out, her abundant hair dissipates like smoke into a corner of the 


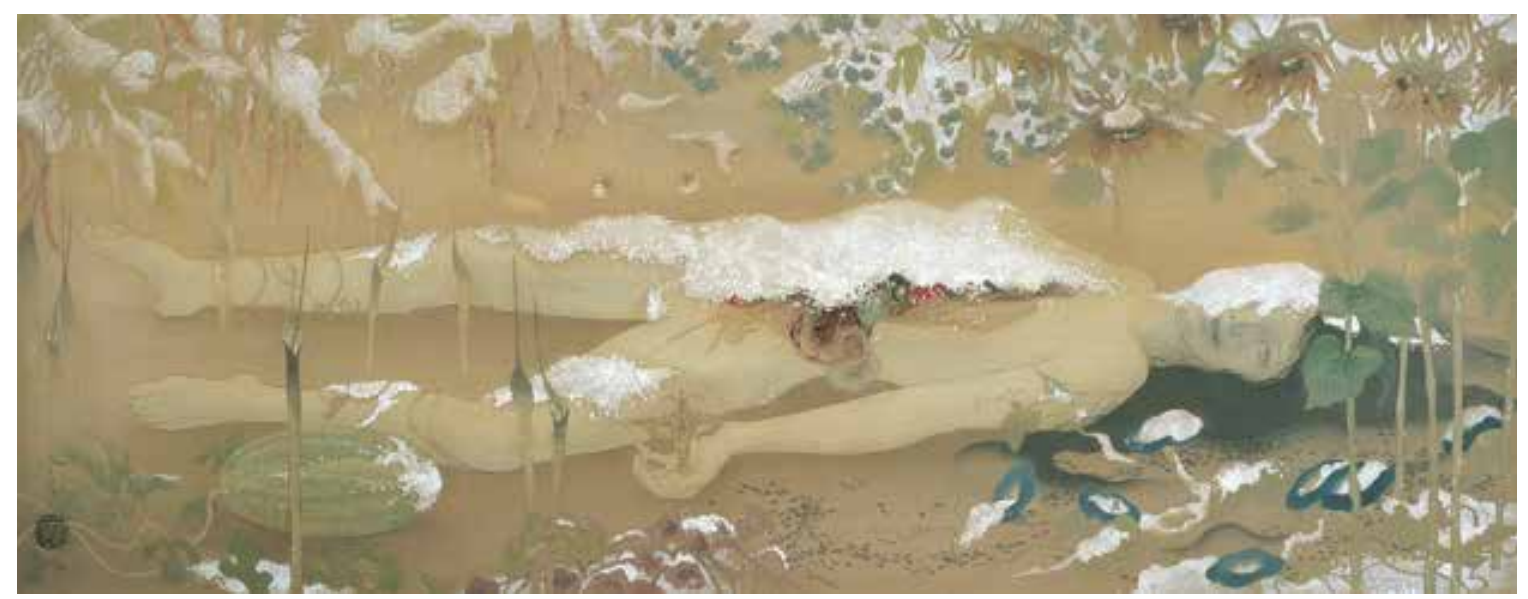

Figure 11. Matsui Fuyuko. Ōsei wa karada o saranai 應声は体を去ら ない (The Parasite Will Not Leave the Body). 2011. H. $30 \mathrm{~cm}$, w. $80 \mathrm{~cm}$. Color on silk. Hanging scroll. Collection of Matsui Fuyuko. With permission of Matsui Fuyuko and Éditions Treville.

painting. The flame-like petals of the orchids obscure her face; a listless hand rests palm upward. Her location and position have both changed, and the flesh on her legs seems to have been chipped away at. "The heart has died in resentment," Matsui writes of this work. "The body is rigid, resembling a single column of smoke." 85 In the third painting, Ōsei wa karada o saranai 應声は 体を去らない (The Parasite Will Not Leave the Body, 2011; figure 11), we appear to be back at the original location, and the positioning of the body is almost identical to that depicted in Keeping Up the Pureness. The relocating and positioning of the corpse is in line with that of older kusōzu images, suggesting its deliberate pose and display as a spectacle. The seventh stage, in Tenkan o tsunagiawaseru 転換を繫ぎ合わせる (Joining the Conversion, 2011), is explained as a suicide driven by the desire to simply rest from an exhaustion caused by personal conflict with reality, and the eighth, Shishi no toìtsu 四肢の統一 (Unification of the Four Limbs, 2011), illustrates the complete casting off of humanity and fusion with the earth. ${ }^{86}$

Translucent, periscope-like ghost flowers, irises, lil-

85 Matsui, Becoming Friends with All the Children in the World, 200. 86 Matsui Midori, "Rongu intabyū," Bijutsu techō, February 2012, 49. ies, and peaches: these flowers and fruits, and others portrayed in the series, evoke the floral renderings of Itō Jakuchū 伊藤若冲 (1716-180o) and other painters of the Japanese canon. Similar influences are seen in the later The Parasite will Not Leave the Body, where maggots that swarm over the body in the shooso 青 瘀相 stage of older models masquerade as impossible Jakuchū-like snowflakes, an unrealistic imagery when we clock the jarring of season, for the flowers tell us it is summer. Likewise, the flowers in Matsui's series reveal a revolting side: all are fully opened, wholly ripened, and heavily sagging, on the verge of rotting indecently into a "garish withering," as George Bataille describes such a state in his writing on "disgust." ${ }^{87}$ The lilies in Keeping Up the Pureness are shown in cross-section displaying their reproductive organs ${ }^{88}$ like a representation of the anatomy through dissection, and as if in

87 Georges Bataille, "The Language of Flowers," Visions of Excess: Selected Writings, 1927-1939 (Minneapolis: University of Minnesota Press, 1985), 12

88 C.B. Liddell, "Pinpricks in the Darkness: The Beautiful and Disturbing Art of Fuyuko Matsui," http://www.culturekiosque. com/art/interview/fuyuko_matsui.html (accessed December 14 2016). Unlike the human, however, female lilies contain both male and female organs, and visibly display both stamen and pistil. Matsui's rendering of flowers as genitalia is evident in some of her other works, such as her 2013 Kōzatsu zu 交雑図 (Interbreeding), and is acknowledged in the portrait painting of her by her contemporary Suwa Atsushi 諏訪敦 (b. 1967) in Hana o taberu 花を食べる (Eating Flowers, 2011), in which she holds a withering lily between her lips. Pictured in Fukuzumi Ren, "Suwa Atsushi intabyū," Bijutsu techō, February 2012, 83. Lilies are often purposely displayed alongside her work when it is on display at Gallery Naruyama. 
sympathetic resonance with the portrayed female, just like the small, igneous shunran 春蘭 orchids and festering chrysanthemums in Crack in the Ashes ${ }^{89}$ By way of these affinities, the flower and the woman each become a part of the other. Also, because she is pregnant, this fusion resembles the imaginary of the rural woman who, in departing her home for the mountains to hide an illegitimate pregnancy, was conceived of as having merged bodily with the site. This trope, suggested by Yanagida Kunio and discussed by Rebecca Copeland, cast the female body as "dangerous, ravenous, haunting the borders of society." 90

In growing around the opened body of the human subject, the flowers cite the "grotesque" in its original aesthetic sense, its Bakhtinian "transgression" and merging, and the instability of boundaries. The weak boundary here-between body and plants (and earth) - is not the only unstable border the fully bloomed and wilting flowers convey. They also capture the instant just prior to falling, a moment of clinging to life before being separated from the plant. Hair, a recurring motif, is expressed in the same way. In Unification of the Four Limbs, under a full but wan moon the windswept strands of black hair caught in faintly brushed tree branches confirm the final separation from the body of the boundary site mentioned above. Matsui describes it as "a kind of boundary site:" "once it's separated from the body it's seen as something disgusting."

To the boundary states expressed by Matsui's work we can add pregnancy itself, or the fetus as an ambiguous "dismember." In Insane Woman Under a Cherry Tree, a ghostly figure holds a fetus to her mouth, seemingly either on the verge of consuming or having just vomited it. Matsui explains this image as an act of vomiting, and she widely regards the depiction of regurgitation of innards as a means of making inner, invisible pain an experience that others can share $e^{92}$ as well as a method of dispelling the other from inside oneself. ${ }^{93}$ In Engraved Altar of Limbs the figure holds a similarly orb-enclosed fetus. The vomiting of a fetus seems an

89 Matsui, Becoming Friends with All the Children in the World, 200 90 Rebecca Copeland, "Mythical Bad Girls: The Crone, the Corpse, and the Snake," in Bad Girls of Japan, eds. Laura Miller and Jan Bardsley (New York: Palgrave Macmillan, 2005), 21

91 Matsui, "Rongu intabyū," Bijutsu techō, February 2012, 43.

92 Nezu Yoshiaki, "Ima o kataru: Itami o kyoyu suru e o gugen ka suru Matsui Fuyuko shi (Gendai bijutsu ka)," Shōkō janaru 38, no.7 (2012): 62.

93 Matsui, Becoming Friends with All the Children in the World, 198. uncannily direct illustration of the grotesque: Ruskin, bewailing the "grotesquerie" produced by Raphael, an artist quite capable of creating "superior" whole bodies rather than dismembered and re-membered ones, called it "an unnatural and monstrous abortion." On the other hand, Insane Woman evokes Beauty (Bijin $z u$ 美人図), an eighteenth-century painting by Soga Shōhaku 曾我蕭白 $(1730-81),{ }^{94}$ himself a forerunner to eroguro, that depicts a distraught woman consumingperhaps - a love letter. The mitate-e-like intervisuality Matsui constructs creates a sophisticated dissonance for the viewer. For those familiar with the eroguro of Yoshitoshi and that of the later Seiu, along with certain folktales, plays, and motifs upon which their work is based, the dissonance is further pronounced. Both artists produced images of women consuming fetuses. In Yoshitoshi's enduring The Lonely House at Adachigahara in $\bar{O}$ sh $\bar{u}$, the fetus inside the belly of a woman suspended upside-down is about to be extracted by the hag Onibaba 鬼婆 for use as an elixir. Seiu depicted this too, notoriously using his own pregnant wife as a model. He also produced a set of three paintings of women consuming fetuses. ${ }^{95}$ Matsui's expulsion of the fetus subverts these images of women, since it is an image intended to allow inner pain, and perhaps a "dismember" or "parasite" (recalling the title of one of her kusōzu paintings) a physical and visible form.

Vomiting is also a form of self-dismemberment. In contemporary eroguro manga, vomiting is a relatively popular motif. According to Bataille-and to Hans Menninghaus - in his study of disgust as an emotion, it is a kind of self-mutilation, an act that demonstrates an ambiguous boundary. In addition to the comparisons already drawn, Matsui's Insane Woman bears compelling similarities to Kanō Hōgai’s 狩野芳崖 (1828-88) Hibo Kannon $z u$ 悲母観音図 (Merciful Mother Kannon, 1888), in which the titular bodhisattva holds a fetus encased in a filmy uterus-like bubble that drops down toward the earth. This is echoed in the image of the womb-enclosed fetus dropping from the mouth of Matsui's woman. It is not unlikely that she is drawing

\footnotetext{
94 Kept at the Nara Prefectural Museum of Art. Matsui, however cites Shōhaku's Yagishita kijo zu 柳下鬼女図 (Ogress Under a Willow Tree, eighteenth century) as recipient of homage here. Matsui Fuyuko, Matsui Fuyuko II (Tokyo: Éditions Treville, 2008), n.p.

95 Untitled. Printed in Geijutsu shinchō, April 1995, 59. Collection of Fukutomi Tarō.
} 
consciously on this famous work, just as her contemporary, photographer Yanagi Miwa やなぎみわ (b. 1967), draws on older works related to her by genre (for her, that of bijin) as well as academic heritage. And both Matsui and Yanagi are re-casting canonical works by artists connected to the prestigious schools they attended. ${ }^{96}$ Here then, in a number of ways, Matsui produces an arrested moment of transition that is captured in both the picture and in the genre itself-a liminal status much more nuanced than the tradition-modern combination by which her work is often characterized, and is close to Bakhtin's grotesque as "body in the act of becoming." The ultimate site of liminality is, of course, the corpse itself.

Returning to the flowers, Matsui remarks that these unnatural flowers represent "a paralysis caused by an overload of fake experiences of beauty"; the surfeit of simulacra can cause a fear that the fake will render the real inferior. ${ }^{97}$ Like the (often unsymmetrical) mirror images that occupy much of Matsui's work, there is for her a monstrosity in perfect beauty ${ }^{98}$ Here too her work seems to draw on the "original" European grotesque, for the Domus Aurea itself was a lush yet artificial paradise, decorated with the intertwining of flora with the human body. But this artificial beauty, incongruous flower garden, and its suicide body have, as we have seen, more of the Japanese eroguro aesthetic in them. Although snakes are not normally a feature of kusōzu (certainly they play no part in the scripturally described practice or any premodern literature or art related to kusozzu), a snake slithers through the ribcage and eye sockets of the skeleton in Matsui's Joining the Conversion. Snakes are to be found as signifiers of female jealousy in premodern visual and literary culture, and in popular religious texts; in Edo-period depictions of female torture; in "freak shows" of the early to mid-twentieth century; and frequently in the S\&M magazines of the postwar kasutori カストリ culture, a commercial, ephemeral subculture that flourished in the postwar period. The

\footnotetext{
96 My Grandmothers cites the subject of Lip Rouge by Okamoto Shinsō 岡本神草 (1894-1933). Yanagi graduated from Kyoto City University of Arts, as did Okamoto. Matsui is from the similarly highly regarded Tokyo University of the Arts. The university museum holds the Kanō painting in its collection. See Szostak, "Fair is Foul, and Foul is Fair," 382-83.

97 Matsui, "Chikaku shinkei toshite no shikaku ni yotte kakusei sareru tsūkaku no fukahi," 53

98 Matsui, Becoming Friends with All the Children in the World, 25,
} 143 snake winding through the eyes of the skull here recalls both Dokuro to tokage 髑髏と蜥蝪 (Skull and Lizard) by Kawanabe Kyōsai as well as an ink piece by Seiu of a snake winding through the eye of a skull, one of a series of ghost paintings, and probably inspired by Kyōsai. ${ }^{99}$ The final stage of Seiu's Shimabara Rebellion, discussed above, features a snake slithering toward a ribcage, and he added the snake to the group of better-known scavengers, the dogs and birds. His own penchant for such an addition most likely derived from his interest in Edo-period torture and punishment, including "snake torture" (hebizeme 蛇責め). ${ }^{100}$ What is perhaps the most arresting section of a kusōzu series in its conventional form, that of the body being consumed by dogs and birds, is conspicuously absent in Matsui's set (so far). But one might take Scattered Deformities in the End as a variation of this stage. A naked woman flees along a forest path, pursued by a bloodthirsty dog that tears hungrily at tendrils of flayed flesh ribboning behind her; birds of paradise peck viciously at her streaming hair. In motion even as her limbs are disintegrating, she is up and running toward (or perhaps, resistant, away from) her death. Haloed by a light that illuminates the green fronds of the trees, her translucent white skin is suffused as if shining out from some inner source. With her uplifted face and eyes set on something beyond the confines of the picture and invisible to the painting's viewer, she appears as a martyred saint whose spirit is dissociated from the trauma of the body, from its searing, widening wounds.

A number of key motifs of the kusōzu are present here: the isolated body of a naked female with long black tresses; parts of the flesh split open to expose sinew, muscle, and organ upon which dogs and birds feed; and the wild, natural environment. ${ }^{101}$ Yet it is different too, mainly in its presentation of the body as alive during this process, which makes the path of death not

99 Seiu's work is in the collection of Kosan Yanagiya. See Mochizuk Aeka, "Kuronawa de musubareta Seiu to watashi," Geijutsu shinchō, April 1995, 60.

100 Itō Seiu and Fujisawa Morihiko, Nihon keibatsu fūzoku zushi (Tokyo: Kokusho, 2010), 161-62.

101 The "sexual subculture language" of the period was of "painful flowers and whimperingly obedient dogs," as Mark Driscoll notes, and that this is used by Edogawa (Driscoll's mention is in relation to Edogawa's Blind Beast) as well as by Seiu indicates another way in which kusōzu resonated with eroguro aesthetics. Mark Driscoll, Absolute Erotic, Absolute Grotesque: The Living, Dead, and Undead in Japan's Imperialism, 1895-1945 (Durham and London: Duke University Press, 2010), 133. 
one of gradual, natural decomposition as in the kusōzu, but a torturous ordeal. Her portrayal shares much with that of Seiu's. The attention to anatomical accuracy is also notable. The flayed areas of the body-strips of skin that become far more elaborate and even fabric-like in Engraved Altar, where the body is wrapped in a ragged flesh robe hemmed with intestines in a grotesque parody of the padded hem (fukiwata ふき綿) of a kimono-visually cite the anatomical illustrations by Jan van Calcar (ca. 1499-1546) for Andreas Vesalius' album De humani corporis fabrica. These showed classically proportioned corpses walking sturdily amid pastoral landscapes and ruins, trailing raggedy coats of skin, occasionally holding the torn strips apart like stage curtains to reveal the inner structure of their bodies. These, and other Western anatomical pictures of the period, are noted for their presentations of the subject as fully alive, and as showing their own internal organs without any pain. However, significantly, it is primarily males shown in this way, whereas the depiction of the female anatomy is limited to a recumbent corpse subject to dissection, womb exposed - such a figure shown prominently on the cover page of De humani corporis fabrica - and a torso. Likewise, later anatomical waxworks of females lie on their backs, and are covered in flesh (both of which contribute to what Jordanova recognizes as a "sleeping beauty" eroticism). ${ }^{102}$ Matsui uses these "anatomical Venuses" in La Specola for her studies. Males were not so, they are "upright muscle men" or "truncated male torsos." 103 The subjects of Matsui's Scattered Deformities and Engraved Altar are subversive in this way too (in addition to the way they upturn the "consumption of fetus" model). Finally, the transcendental ecstasy and ethereality on the face of the female subject of the Matsui paintings, and the eye contact of subject with viewer in Keeping up the Pureness hint at a kind of willing and joyful, even martyr-like submission, an impression reinforced by Matsui's description of the opened torso and abdomen as an act of "flaunting" through suicide. This apparent agency of the subject in Matsui's work is suggested by the mutually reinforcing confluence of conventions of anatomical depiction; expressions of religious ecstasy or martyrdom; and $k u s \bar{z} z u$ ideas around exposure as salvation. ${ }^{104}$

\footnotetext{
102 Jordanova, Sexual Visions, 50

103 Ibid., 45

104 There is evidence of desire by some nuns and aristocratic women in medieval China of having their bodies posthumously
}

Although seventeenth- and eighteenth-century European anatomical models influence the figures portrayed in Matsui's kusōzu and many of her other works, the native interpretation, practice, and depiction of anatomy are also factors at play. Dissection and surgery were introduced into Japan by Dutch doctors in the Edo period. Kanpō 漢方 (Chinese medicine), widely used before this, did not require incision of the body for the purposes of healing, and it was in part because of this that both the popular and professional visual culture of anatomy caused much horror to its audience. ${ }^{105}$ According to Timon Screech, dissection for the purpose of anatomical understanding was perceived by many as “a literal shitai sarashi”106 死体晒し, the public exposure and slicing of a criminal's body after death. In fact, criminals' corpses were used for medical inquiry. Kusōzu bodies might be compared to those of offenders, and via the connection with medicine both the kusōzu body and the criminal body can be associated with the anatomical body in Edo culture. Kusōzu pictures converge with both the visual language of anatomical representations and the aesthetic of the grotesque. First of all, in the premodern paintings the landscapes are lonely wastelands-sites where bodies were (in reality) discarded, often unburied. These bodies were especially those made impure not only by death itself, and by potentially contagious diseases, but were also marked by death of a certain kind (the social disgrace of an execution, for instance, or perhaps the isolated death of a person who lacked familial support). During the Edo period, if not earlier, the exposed corpse was by definition the criminal one. ${ }^{107}$ It was considered permissible to posthumously punish a criminal's body through physical violence or exposure (for example, the previously mentioned shitai shirashi) ${ }^{108}$ Perhaps a parallel with the exposed, mutilated criminal

exposed for the benefit of others, and a similar discourse existed in Japan, but the discussion this deserves is beyond the parameters of this paper. See, for example, Shufen Liu, "Death and Degeneration of Life: Exposure of the Corpse in Medieval Chinese Buddhism," Journal of Chinese Religions 28 (2000): $1-30$

105 Timon Screech, "The Birth of the Anatomical Body," Births and Rebirths in Japanese Art: Essays Celebrating the Inauguration of the Sainsbury Institute for the Study of Japanese Arts and Cultures, ed. Nicole Coolidge Rousmaniere (Leiden: Hotei Press, 2001), 93-4.

106 Ibid., 101

107 lbid., 101.

108 Ibid., 100. 
and that of the female of kusōzu can be found: already blameworthy for inciting male desire, she could then be further abused through exposure and then violation by animals, performing a similar role of distinguishing profane and sacred/social. Wilson has drawn attention to post-Ashokan texts that tell of practices of physically inscribing punishment on the offending body parts of women, and then displaying these for the edification of the monastic community. ${ }^{109}$ Secondly, format indicates a link between $k u s \bar{z} z u$ and the visual culture of anatomy. In its presentation as a series, the former is linked to early anatomical illustrations since these were most often formatted as handscrolls, and for the same reason as that which guided the serial formatting of the Buddhist image: to best lead the viewer through a sequence of stages of dismantlement.

These points should be kept in mind: Matsui's kusōzu corpses evoke motifs informed by a "modern" treatment of discarded, expedient corpses (which nonetheless induced horror in general perception), and their use in anatomical study and dissection. At the same time, however, we also find an explicit rendering of the kusozzu in the modern paintings by Seiu that connect it to male sexual desire and corporal punishment of the objects of that desire. Where these converge is in the idea and practice of the punishment of the criminal corpse. ${ }^{110}$ In fact, a convergence of the three is displayed in an early nineteenth-century illustration by Utagawa Toyokuni 歌川豊国 (1769-1825; figure 12). This is of a medicine shop and a sign that shows what appears to be a kusōzu-like female corpse being operated upon (or cut up, or violated, depending on the visual culture through which one perceives) by "Dutch" doctors." Toyokuni's illustration also shows an anatomical doll (dō-ningyo 銅人形, “copper doll”). As a figure that "flaunts" her anatomy, the figure in Keeping Up the Pureness resembles these anatomical models. They were produced from the mid-eighteenth century onward, and were figures holding their torsos open to expose their anatomy for the purposes of education-

109 Wilson, "The Female Body as a Source of Horror and Insight in Post-Ashokan Indian Buddhism," 79-81.

110 This is something in which Seiu would have been interested, having authored a book between 1946 and 1952 on the history of criminal punishment in Japan, as mentioned above.

111 It appears in Santō Kyōden's 山東京伝 (1761-1816) 1806 Mukashi gatari inazuma byōshi 昔語稲妻表紙 (An Ancient Tale with a Lightning Cover). See Screech, "The Birth of the Anatomical Body," 117-18.

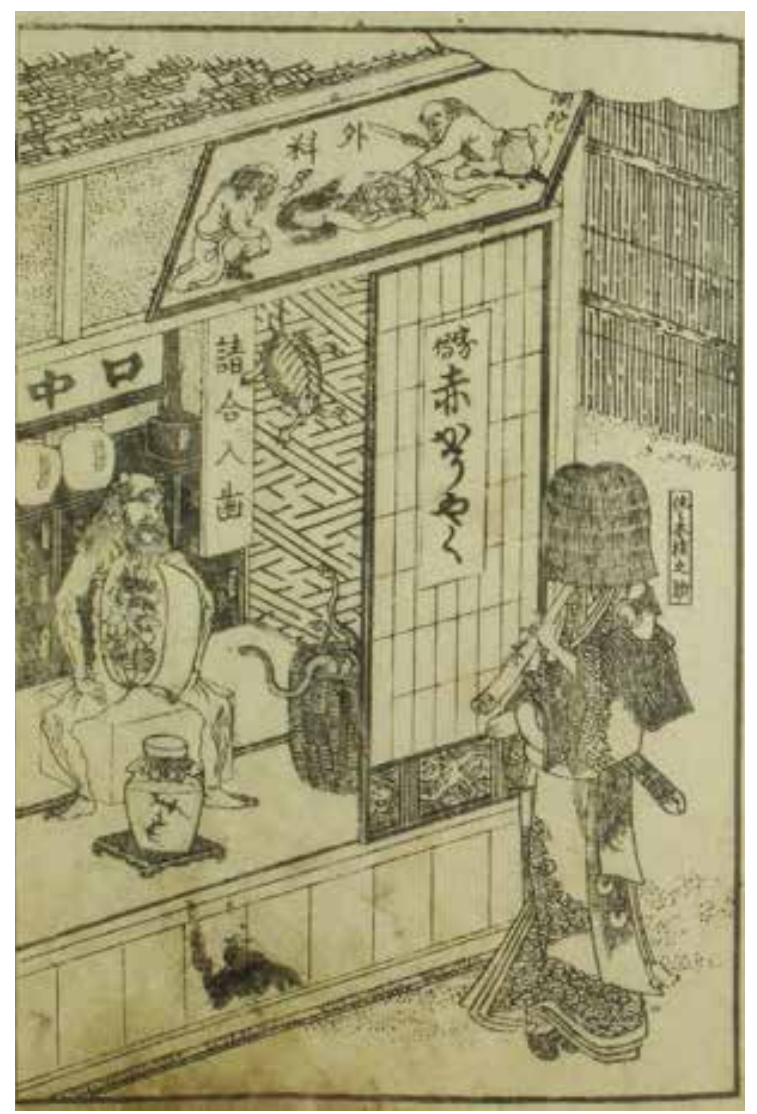

Figure 12. Utagawa Toyokuni. Print illustration to Santō Kyōden's Mukashi gatari inazuma byōshi 昔語稲妻表紙 (An Ancient Tale with a Lightening Cover). 1806. H. ca. $23 \mathrm{~cm}$. Source: http://archive.wul. waseda.ac.jp/kosho/he13/he13_03150/ (last accessed February 28, 2017)

and spectacle. Seiu also made an illustration of a lifesize female anatomical doll with an opened torso and abdomen. ${ }^{112}$ Perhaps what is being produced in this period cannot strictly be called eroguro, which dates from the 1920 or so, except in the descriptive sense. But once in the realm of eroguro, again a confluence of these very same motifs is utilized in a story by Rampo. A medicine shop owner in Rampo's 1925 story, Hakuchūmu 白 昼夢 (The Daydream), is revealed to have murdered his wife but to be getting away with the crime in broad daylight by presenting her body as a "wax mummy" in the

112 Pictured in Geijutsu shinchō, April 1995, 52. Name of owner not provided. 
window of his pharmacy. Before an entire crowd the man confesses his crime in the guise of an entertaining story: he gives evidence transparently, yet simultaneously obscures it through his presentation of confession as fiction and victim as waxwork anatomical model. In these ways Hakuchümu presents the essence of the grotesque by fusing what is normally distinct, and demonstrates the camouflage of the socially taboo by the socially acceptable: an entertaining yarn is the confession of a brutal murder and an anatomical model its material evidence. This both caters to and critiques the consumer's appetite for sensational eroguro material of the time, a dual effort discerned in other of Rampo's works, as Driscoll has pointed out. ${ }^{113}$ Similarly, in Rampo's Mōjū 盲獣 (Blind Beast), published six years after Hakuchūmu, department store managers admire shop window mannequins sold to them by a murderer who has assembled them from the dismembered parts of his victims. Murder and the grotesque in both cases produce "modernizing effects" (to paraphrase Driscoll), ${ }_{1}^{14}$ since the anatomical model that signified advanced western medicine denoted modernity in the Edo period, as the department store window display model did in the Taishō period, but both carried undertones of violence and the dismembered (female) body. Once again, the grotesque and the modern appear as flipsides of each other.

This Edo-period perception of penetration of the body's boundaries, the presentation of it using a female body, and the display of the exposed and opening female body in kusōzu, are assembled in Matsui's kusōzu. The opened abdomen of Keeping up the Pureness can now be read as both self-disembowelment (seppuku) according to Matsui's explanation-and anatomical dissection. It only slightly resembles the stage of kusōzu in which the body is opened, but it is intended to function in a comparably soteriological way. Like other of her works, there is a self-exposure for the sake and salvation of the viewer, but the masochism of this is claimed as a last-resort demonstration of power as well as a way of communicating with "potential rapists." The

113 Driscoll, Absolute Erotic, Absolute Grotesque, 216-21. The façade of entertainment conjured up by both the storyteller and Rampo himself is further adorned by the marching-band singing of soldiers stationed in Manchuria that parades by as the man reaches the climax of his confession; the resounding drums accompany his speech as they fade out. It may also have been an implicit critique of the imperial ambitions of Japan. 114 lbid., 138 portrayal of female seppuku and of the resulting mound of viscera is a highly charged eroguro image today, exemplified in the extreme work of manga artist Uziga Waita 氏賀Y太 (b. 1970) and the zines and fetish-club shows of S\&M performer Saotome Hiromi 早乙女宏 美 (b. 1963). Matsui presents it rather more delicately in her pencil drawing Conception (fig. 7), which she developed into the 2013 painting Ayatori jozu 綾取女圖 (String Figuring [cat's cradle] Woman). A young naked woman sits comfortably on a chair casually unspooling her guts, perhaps parodying the triumphal completion of an ideal seppuku, in which a samurai would pull out his innards. Certainly the subject of seppuku as punishment, ideal or honorable military suicide, and its changing meanings, requires more attention here. But it is worth pointing out at least that the visual culture of female seppuku arose in postwar eroguro publications. As the image appears in present-day eroguro and S\&M subculture, it is the latest manifestation of the confluence of seppuku with eroticized female self-sacrifice and exposure. Yet Matsui's suicides are not acts to be celebrated. She writes that "failed suicides are the result of a dissociated part of the self stepping in: if the greater part of the self is hatred . . . then the dissociated part will be at least a little warm and loving, and it is this part that comes in to prevent suicide." 115 This psychological explanation of her work introduces the final issues I wish to address here: the significance of viewing and the function of visual representation.

\section{Conclusion}

Fuse Hideto's essay on Matsui's oeuvre indulges the potential for a catalogue of work at any time in its development to be arranged freely into a kind of story, much like a personal collection, regardless of the artist's intentions. ${ }^{116}$ And he creates (as I have) a narrative kusōzu by including paintings not stated as kusōzu stages by Matsui, as well as counting some works such as those of "dogs, snakes and flowers ... as decorative elements in the periphery of the Kusōzu."117 Certainly her work in

\footnotetext{
115 Matsui, "Chikaku shinkei to shite no shikaku ni yotte kakusei sareru tsūkaku no fukahi," 32

116 Hideto Fuse, "The World of Matsui Fuyuko," in Becoming Friends with All the Children in the World, ed. Fuyuko Matsui (Tokyo: Editions Treville, 2013), 2O-2. 117 Ibid., 22.
} 
its entirety can be said to be deeply informed by issues of boundaries and their dissolution, and we have come to identify this interest in premodern kusōzu as, in fact, invested in the modern aesthetics of eroguro, and the negotiations that eroguro operates with premodern imagery and modernity itself. Her own references to rape in connection to her kusōzu figures must be viewed in the context of the modern kusōzu discussed above that depict sexual assault. Matsui describes her paintings as talismans, and in this sense they may be considered extraordinarily compassionate works. They are meant to horrify and to dissuade, in part through, she says, a sharing of pain that is normally utterly confined to one's self and is thus inexpressible, ${ }^{118}$ as Elaine Scarry has discussed. The figures shown in her works can be seen as "surrogates" or "purifying agents," "enabling those who look at them to avoid actual injury to themselves," and to help the viewer, including the "potential rapist" to understand the (suicidal) agony of the other: ${ }^{119}$ "I want the audience to see my works in order to help them get rid of the evil from their bodies." 20

Yamamoto remarks that Matsui's portrayals of exposed human organs "show us our true power to look unflinchingly at the truth without turning a blind eye to suffering and agony," ${ }^{121}$ and they do reflect a Ruskian understanding of the "grotesque" image. Ruskin (as well as Wolfgang Kayser in his 1966 work) presented such portrayals as a way of engaging playfully with terror in order to exorcise it on both individual and cultural levels. ${ }^{122}$ In this sense again, though, Matsui's images share common ground with the ostensible function of early kusōzu: salvation of the one through the revelation/presentation of the grotesque reality of the other. This also reflects one side of the perennial conventional argument surrounding images of sex, violence, horror, and pornography, ${ }^{123}$ an argument that has also attended kusōzu: do disturbing images offer transformation and liberation to the viewer (often this investiture of liber-

118 Asian Art Museum, Fuyuko Matsui on Her Work and the Supernatural, https://www.youtube.com/watch?v=U-ExreP3NSQ, 2012 (accessed December 14, 2016).

119 Matsui, Becoming Friends with All the Children in the World, 169.

120 C.B. Liddell, Exhibition: The Bewitching Art of Fuyuko Matsui, http://travel.cnn.com/tokyo/visit/exhibition-bewitching-art-fuyuko-matsui-149215/, 2012 (accessed December 14, 2016).

121 Matsui, Becoming Friends with All the Children in the World, 125.

122 In both Modern Painters and The Stones of Venice. This is only one aspect of Ruskin's multivalent theory of the grotesque.

123 Arguably, these are not mutually exclusive. ation is extended to the portrayed subject as well), or do they legitimate and reinforce essentialistic understandings of the portrayed (and the viewing) body? The argument rests on opposing models of catharsis and articulation, both of which assume psychoanalytical ideas of 'the beast within,' ideas that,

... see repression as a constitutive feature of
human development, the mechanism through
which we are constrained to overcome the
(anti-social) desires of infancy. The primary focus
for this repression is sexuality, and horror, in a
variety of ways, acts as a channel for expression of
the repressed affect. In so doing it sustains order,
whether by cathartic release of otherwise threaten-
ing urges or by reinforcing acceptance of repressive
taboos presumed to be essential to social survival. ${ }^{124}$

Kusōzu collapse the two sides of the question: the liberation of the viewer relies upon the essential grotesqueness of the female body. It may be proposed that the various frames of reference through which I have viewed Matsui's works prompt similar processes of gazing. Meditational practice related to kusōzu images (but not necessarily practically or in reality) aimed for a kind of "equilibrium" in the face of the disaggregated body (even if meditators ostensibly also sought recognition of the [Buddhist] self there). Philomena Horsley in her study of medical students of anatomical dissection, observes that their "challenge is to find, and keep their equilibrium amidst the mess of the dismantled body.... [I]mmersive factors [are] deemed necessary to disengage from any unsettling emotional and social associations of the corpse." 25 The images presented in the genre of body-punishing horror that find their roots (in Japan) in the eroguro aesthetic that Matsui shares ${ }^{126}$ also aim at the closure of the (male) body through con-

\footnotetext{
124 Andrew Tudor, "Why Horror? The Peculiar Pleasures of a Popular Genre," Cultural Studies 11 (1997): 448. My italics.

125 Philomena Horsley, "Teaching the Anatomy of Death: A Dying Art?" Medicine Studies 2, no. 1 (June 2010): 11.

126 Matsui may not wish her work to be classed as pornography or of sharing in its aesthetic; in her doctoral dissertation she condemns the sexualized portrayal of women found in the work of Aida Makoto 会田誠 (b. 1965). See Matsui, "Chikaku shinke toshite no shikaku ni yotte kakusei sareru tsūkaku no fukahi," 36-7. Although her art crosses many categories, it may occupy the category of contemporary eroguro, as I have indicated.
} 
templation of (that is, contrast with) ${ }^{127}$ the unbounded and ruptured (female) one. These three frames are not adversarial: they converge in what might be expressed as "eroguro-dissection-kusōzu," making them, indeed, extraordinary sights that themselves offer to the present-day viewer and scholar too the challenge of maintaining equilibrium and retaining empathy and shock appropriate as ethical meter, but without taking on the burden of suffering as a martyr or an identification that psychologically scars. Elisabeth Bronfen presents a valuable discussion of this problem in Over Her Dead Body, observing the gender-divided responses to paintings of dead women, and pressing the choice scholars must make in their treatment of these and similar images. ${ }^{128}$ The image is implicated in its own lack of boundaries, in that it remains potent over the centuries; in other words, it remains to be resolved. Here, the concept of the uncanny works to describe the process I have proposed, by which an image might survive even when not immediately recognizable, and also to capture the core commonality between the representational contexts in which it appears. Bronfen's explanation of the uncanny, though made in reference to a quite different cultural sphere, is useful here. "The uncanny," she writes, "always entails anxieties about fragmentation, about the disruption or destruction of any narcissistically informed sense of personal stability, body integrity, immortal individuality." 129

Commentators and audiences tend to laud Matsui's mastery of the traditional (subject matter as well as the nihonga style and technique), her earlier training in Western oil painting, and her reworking of the former in the contemporary Japanese art scene. This reading, however, unproblematically juxtaposes and presents a historical narrative and hermeneutics of influence that links tradition to (post-)modernity and results in an elision of key loci of influences situated in the late-nineteenth- and mid-twentieth-century marginalized visual

127 Barbara Creed writes that "viewing the horror film signifies the desire not only for perverse pleasure (confronting sickening, horrific images/being filled with terror/desire for the undifferentiated), but also a desire, once having been filled with perversity, taken pleasure in perversity, to throw up, throw out, eject the abject (from the safety of the spectator's seat)." Barbara Creed, The Monstrous-Feminine: Film, Feminism, Psychoanalysis (London: Routledge, 1993), 10. My italics.

128 See, especially, Elisabeth Bronfen, Over her Dead Body: Death, Femininity, and the Aesthetic (Manchester: Manchester University Press, 1992), 39-56.

129 Bronfen, Over her Dead Body, 113 cultures of Japan. It also acquiesces with a dominant view of modern Japanese culture (which I think can be extended to apply to contemporary culture as well) as being "an interplay between external Western influence and a reactive 'native' consciousness, which in at least the better instances culminates in a turn back to the tradition." ${ }^{130}$ This misses the importance of counter-influence and the complexity of the way in which subjects, aesthetics, and so on are received into a culture primed to receive them in specific ways, and it runs the risk of reifying Japanese tradition in distinction to "Western" tradition. Without by any means discounting Matsui's conscious use of the Buddhist model, I have disagreed with this approach, and it is the influence of a marginalized culture - eroguro - to which I have drawn attention in this essay. While Matsui's work is lauded as a successful meeting of East and West in technique, style, and (sometimes) subject matter, it proves a discomforting encounter to witness. The "Western" and "Eastern" allusions are both to violence and cruelty, and to the morbid aspects of Buddhism and Christianity (ecstasy or martyrdom). Nihonga, Japanese painting originally developed to present authentic Japanese identity in contrast to Western influences, is employed, rather, to depict "lower-class" fare (Bataille's "base material") violence; death; the supernatural-and thus departs from sanctioned subject matter. There is an uneasiness evoked by Matsui's subverted use of Meiji-era Japanese ledgers of Western modernity that simultaneously undermine the claim they make: anatomical records taken in a direction in their visual portrayal that is beyond any educational or medical purpose (and toward grotesque spectacle related to cadaver mutilation) or a classical body, already a dismembered and grotesque thing, born prematurely disfigured from excavations. Her combination of the Buddhist kusōzu, European renaissance art and its classical body, anatomical models, and the erotic-grotesque that began at the end of the nineteenth century and has flourished as a subculture up to the present day, is an accurate capture of the contradictions that attend, or are inherent in, the modernity that is incarnated in her work.

130 Alan Stephen Wolfe, Suicidal Narrative in Modern Japan: The
Case of Dazai Osamu (Princeton: Princeton University Press, 1990), 26-7. 


\section{Bibliography}

\section{NOTE ON ABBREVIATION}

T Taishō shinshū daizōkyō 大正新修大蔵経. Edited by Takakusu Junjirō 高久楠順次郎 and Watanabe Kaikyoku 渡辺海旭. 100 vols. Tokyo: Taishō Issaikyō Kankōkai, 1924-35.

\section{PRIMARY SOURCES}

Aśvaghosa, edited and translated by Edward B. Cowell. The Buddha-karita, or, Life of the Buddha. New Delhi: Cosmo Publications, 1977.

Bikkhu Bodhi. The Numerical Discourses of the Buddha: A Translation of the Ainguttara Nikāya. Boston: Wisdom Publications, 2012.

Bikkhu Bodhi and Bikkhu Nanamoli. Teachings of the Buddha: The Middle Length Discourses of the Buddha: A Translation of the Majjhima Nikaya. Somerville, MA: Wisdom Publications, 2005.

Nāgārjuna, translated by Kumārajīva. Mahāprajñā Pāramitā Sastra 大智度論. T.1509, 25.

Zhiyi 智顗. Mohe zhiguan 摩訶止観. T.1911, 46.

- . Fa-hua-hsuan-i 法華玄義. T.1716, 33.

\section{SECONDARY SOURCES}

Asian Art Museum. "Fuyuko Matsui on Her Work and the Supernatural." Asian Art Museum. July 18, 2012. https:// www.youtube.com/watch?v=U-ExreP 3 NSQ (last accessed December 14, 2016).

Angles, Jeffrey. "Seeking the Strange: Ryōki and the Navigation of Normality in Interwar Japan." Monumenta Nipponica 63, no. 1 (2008): 101-41.

Bakhtin, Mikhail. Rabelais and His World, translated by Helene Iswolsky. Bloomington: University of Indiana Press, 1984.

Berndt, Jaqueline. "Nationally Naked? The Female Nude in Japanese Oil Painting and Posters 1890s-1920s." In Performing the Nation: Gender, Politics, and the Visual Arts of China and Japan (189os-1920s). Edited by Doris Croissant, Catherine Vance Yeh, and Joshua S. Mostow, 307-45. Leiden: Brill, 2008.

Bronfen, Elisabeth. Over Her Dead Body: Death, Femininity, and the Aesthetic. Manchester, UK: Manchester University Press, 1992.

Chin, Gail. "The Gender of Buddhist Truth: The Female Corpse in a Group of Japanese Paintings." Japanese Journal of Religious Studies 25, no. 3-4 (1998): 277-317.
Copeland, Rebecca. "Mythical Bad Girls: The Crone, the Corpse, and the Snake." In Bad Girls of Japan. Edited by Laura Miller and Jan Bardsley, 15-31. New York: Palgrave Macmillan, 2005.

Creed, Barbara. The Monstrous-Feminine: Film, Feminism, Psychoanalysis. London: Routledge, 1993.

DeWitt, Lindsey E. "A Mountain Set Apart: Female Exclusion, Buddhism, and Tradition at Modern Ōminesan, Japan." PhD diss., University of California, Los Angeles, 2015.

Driscoll, Mark. Absolute Erotic, Absolute Grotesque: The Living, Dead, and Undead in Japan's Imperialism, 1895-1945. Durham and London: Duke University Press, 2010.

Eubanks, Charlotte. Miracles of the Book and Body: Buddhist Textual Culture and Medieval Japan. Berkeley, Los Angeles, and London: University of California Press, 2011.

Faure, Bernard. The Red Thread: Buddhist Approaches to Sexuality. Princeton: Princeton University Press, 1998.

Foxwell, Chelsea. "Merciful Mother Kannon and Its Audiences." The Art Bulletin 92, no. 4 (2010): 326-47.

Fukuzumi Ren 福住廉. “Suwa Atsushi intabyū 諏訪敦イン タビュー.” Bijutsu techō 美術手帳, February 2012.

Fuse, Hideto. “The World of Matsui Fuyuko." In Becoming Friends with All the Children in the World. Edited by Fuyuko Matsui, 20-2. Tokyo: Éditions Treville, 2013.

Harpham, Geoffrey. On the Grotesque: Strategies of Contradiction in Art and Literature. Princeton, NJ: Princeton University Press, 1982.

Hasegawa, Yūko. "In the Realm of Hell.” Tate Etc. September 1, 2009. http://www.tate.org.uk/context-comment/articles/realm-hell (last accessed January 20, 2017).

Horsley, Philomena. "Teaching the Anatomy of Death: A Dying Art?” Medicine Studies 2, no.1 (2010): 1-19.

Itō Seiu 伊藤晴雨. Irohabiki: Edo Tōkyō fūzoku yashi いろ は引き江戸東京風俗野史. 6 vols. Tokyo: Kōbunkan, Rokkōkan, Jōhoku shoin, 1927-32.

Yasuda Korekushon 5: Rongo tsūkai Jigoku no onna 安田コレクション: 論語通解 ·地獄の女. Tokyo: Ginza shokan, 1930.

Itō Seiu and Fujisawa Morihiko 藤沢衛彦. Nihon keibatsu $f \bar{u} z o k u$ zushi 日本刑罰風俗図史. 3 vols. Reprinted. Tokyo: Kokusho, 2010.

Izumi Takeo 泉武夫, Kasuya Makoto 加須屋誠, and Yamamoto Satomi 山本聡美, eds. Kokuhō: Rokudōe 国宝六道 絵. Tokyo: Chūo Kōron Bijutsu Shuppan, 2007.

Jordanova, Ludmilla. Sexual Visions: Images of Gender in Science and Medicine between the Eighteenth and Twentieth Centuries. Wisconsin: University of Wisconsin Press, 1989. 
Kaminishi, Ikumi. “Dead Beautiful: Visualizing the Decaying Corpse in Nine Stages as Skillful Means of Buddhism." In A Companion to Asian Art and Architecture: Blackwell Companions to Art History. Edited by Rebecca Brown and Deborah Hutton, 514-36. Chichester, West Sussex, UK; Malden, MA: Wiley-Blackwell, 2011.

Kanda, Fusae. "Behind the Sensationalism: Images of a Decaying Corpse in Japanese Buddhist Art." The Art Bulletin 87, no. 1 (2005): 24-49.

Keene, Donald. Modern Japanese Literature: From 1868 to the Present Day. New York: Grove Press, 1956.

Kimbrough, R. Keller. "Sacred Charnel Visions: Painting the Dead in Illustrated Scrolls of The Demon Shuten Dōji." In Japanese Visual Culture: Performance, Media, and Text (Research Reports of Projects, Comprehensive Research of Japanese Illustrated Books in the USA). Edited by Kenji Kobayashi, Maori Saitō, and Haruo Shirane, 35-48. Tokyo: National Institute of Japanese Literature, National Institutes for the Humanities, 2013.

Koizumi Hiroshi 小泉弘 et al., eds. Hōbutsushū. Kankyo no tomo. Hirasan kojin reitaku 宝物集 · 閑居友 ·比良山古 人霊託. Vol. 40 of Shin Nihon koten bungaku taikei 新日 本古典文学大系. Tokyo: Iwanami Shoten, 1993.

Kuriyama, Shigehisa. "Between Mind and Eye: Japanese Anatomy in the Eighteenth Century." In Paths to Asian Medical Knowledge. Edited by Charles Leslie and Allen Young, 21-43. Berkeley and Los Angeles: University of California Press, 1992.

Liddell, C.B. "Pinpricks in the Darkness: The Beautiful and Disturbing Art of Fuyuko Matsui." Culturekiosque. October 9, 2007. http://www.culturekiosque.com/art/ interview/fuyuko_matsui.html (last accessed December 14, 2016).

. "Exhibition: The bewitching art of Fuyuko Matsui." CNN Travel. January 13, 2012. http://travel.cnn.com/ tokyo/visit/exhibition-bewitching-art-fuyuko-matsui-149215/ (last accessed December 14, 2016).

Liu, Shufen. "Death and Degeneration of Life: Exposure of the Corpse in Medieval Chinese Buddhism." Journal of Chinese Religions 28 (2000): 1-30.

Maruo Suehiro 丸尾末広. Panoramatō kidan パノラマ島奇 談. Tokyo: Kadokawa, 2008.

Matsui Fuyuko 松井冬子. Matsui Fuyuko II 松井冬子II. Tokyo: Éditions Treville, 2008.

- "Chikaku shinkei toshite no shikaku ni yotte kakusei sareru tsūkaku no fukahi 知覚神経としての視覚に よって覚醒される痛覚の不可避.” PhD diss., Tokyo University of the Arts, 2007.
Matsui, Fuyuko, ed. Becoming Friends with All the Children in the World. Tokyo: Éditions Treville, 2013.

Matsui Midori 松井みどり. “Rongu intabyū ロング・イン タビュー.”Bijutsu techō. February 2012.

Menninghaus, Winfried. Disgust: Theory and History of a Strong Sensation. Stanford: Stanford University Press, 2003.

Mochizuki Aeka 望月あえか. “Kuronawa de musubareta Seiu to watashi 黒縄で結ばれた晴雨と私.” Geijutsu shinchō芸術新潮. April 1995.

Moerman, D. Max. "Dying Like the Buddha: Intervisuality and the Cultic Image." Impressions: The Journal of the Japanese Art Society of America 29 (2007-08): 24-57.

Nezu Yoshiaki 根津義明. “Ima o kataru: Itami o kyōyū suru e o gugen ka suru Matsui Fuyuko shi (Gendai bijutsu ka) 今を語る：痛みを共有する絵を具現化する松井冬 子 (現代美術家) ."Shōkō jānaru 商工ジャーナル 38 , no. 7 (2012): 62-5.

Nelson, Maggie. The Art of Cruelty: A Reckoning. New York: W.W. Norton \& Company, 2011.

Nakano Genzō 中野玄三. Rokudōe no kenkyū 六道絵の研 究. Kyoto: Tankōsha, 1989.

Pandey, Rajyashree. "Desire and Disgust: Meditations on the Impure Body in Medieval Japanese Narratives." Monumenta Nipponica 6o, no. 2 (2005): 195-234.

Pflugfelder, Gregory M. Cartographies of Desire: Male-Male Sexuality in Japanese Discourse 1600-1950. Berkeley: University of California Press, 2000.

Reichart, Jim. "Deviance and Social Darwinism in Edogawa Rampo's Erotic-Grotesque Thriller, Kotō no oni." Journal of Japanese Studies 27, no.1 (2001): 113-41.

Russo, Mary J. The Female Grotesque: Risk, Excess and Modernity. New York: Routledge, 1995.

Satō, Dōshin. Modern Japanese Art and the Meiji State: The Politics of Beauty. Los Angeles: The Getty Research Institute, 2011.

Scarry, Elaine. The Body in Pain. Oxford: Oxford University Press, 1987.

Screech, Timon. "The Birth of the Anatomical Body." In Births and Rebirths in Japanese Art: Essays Celebrating the Inauguration of the Sainsbury Institute for the Study of Japanese Arts and Cultures. Edited by Nicole Coolidge Rousmaniere, 83-140. Leiden: Hotei Press, 2001.

Silverberg, Miriam. Erotic Grotesque Nonsense: The Mass Culture of Japanese Modern Times. Berkeley and Los Angeles: University of California Press, 2007.

Slaymaker, Douglas. The Body in Postwar Fiction: Japanese Fiction after the War. New York: Routledge, 2004. 
Stephens, Elizabeth. Anatomy as Spectacle: Public Exhibitions of the Body from 1700 to the Present. Liverpool: Liverpool University Press, 2011.

Suzuki Sadami 鈴木貞美. “Ero, guro, nansensu no keifu 工 ロ・グロ・ナンセンスの系譜.” In Ranpo no jidai: Shōwa ero, guro, nansensu 乱歩の時代 昭和エロ · グ ロ・ナンセンス. Edited by Yonezawa Yoshihiro 米沢嘉 博, 8-13. Tokyo: Heibonsha, 1995.

Suzuki Shōsan 鈴木正三. Shichinin bikuni. Ogura monogatari. Ninin bikuni. Ikkyū mizukagami. Ikkyū gaikotsu. Kusōshi 七人比丘尼 小倉物語 二人比丘尼 一休 水鏡 一休骸骨 九相詩. Tokyo: Benseisha, 1973.

Szostak, John D. "Fair is Foul, and Foul is Fair: Kyoto Nihonga, Anti-Bijin Portraiture and the Psychology of the Grotesque." In Rethinking Japanese Modernism. Edited by Roy Starrs, 362-83. Leiden: Koninklijke Brill NV, 2012.

Tanaka Takako 田中貴子. “Saiganji shozō 'Kusōzu’ etoki 'saisei' no kokoromi 西岸寺所蔵「九相図」絵解き「 再生」の試み.” December 2, 2014. Kasamashoin online. http://kasamashoin.jp/2014/12/57_16.html (last accessed January 4, 2017).

Tanigawa Atsushi 谷川渥. Haikyo no bigaku 廃墟の美学. Tokyo: Shūseisha, 2003.

Tudor, Andrew. "Why Horror? The Peculiar Pleasures of a Popular Genre." Cultural Studies 11, no. 3 (1997): 443-63

Wilson, Elizabeth. Charming Cadavers: Horrific Figurations of the Feminine in Indian Buddhist Hagiographical Literature. Chicago and London: University of Chicago Press, 1996.

. "The Female Body as a Source of Horror and Insight in Post-Ashokan Indian Buddhism." In Religious Reflections on the Human Body. Edited by Jane Marie Law, 76-99. Bloomington and Indianapolis: Indiana University Press, 1995.

Wolfe, Alan Stephen. Suicidal Narrative in Modern Japan: The Case of Dazai Osamu. Princeton, NJ: Princeton University Press, 1990.

Yamamoto Satomi 山本聡美. Kusōzu o yomu: Kuchite yuku shitai no bijutsushi 九相図を読む 朽ちてゆく死体の 美術史. Tokyo: Kadokawa, 2015.

“Matsui Fuyuko, Kyūshū de kusōzu o miru 松井冬 子、九州で九相図を観る.” Geijutsu shinchō. October 2012.

Yamamoto Satomi and Nishiyama Mika 西山美香, eds. Kusōzu shiryō shūsei: Shitai no bijutsu to bungaku 九相 図資料集成 死体の美術と文学. Tokyo: Iwata Shoin, 2009.
Yamamoto, Satomi. "Beyond." In Becoming Friends with All the Children in the World. Edited by Fuyuko Matsui, 169. Tokyo: Éditions Treville, 2013.

. "Death and Disease in Medieval Japanese Painting." Kinjō Gakuin Daigaku ronshü jinbun kagaku hen 金城学 院大学論集人文科学遍 6, no. 2 (2010): 81-96.

Yasumura Toshinobu 安村敏信. “Motîfu: Katachi yokereba subete yoshi モティーフ：かたちよければすべてよ し." Geijutsu shinchō. April 2014. 